in vivo $33: 1011-1026(2019)$

doi:10.21873/invivo.11570

Review

\title{
Plasma Medicine: A Field of Applied Redox Biology
}

\author{
THOMAS VON WOEDTKE ${ }^{1,2}$, ANKE SCHMIDT ${ }^{1}$, SANDER BEKESCHUS ${ }^{3}$, \\ KRISTIAN WENDE ${ }^{3}$ and KLAUS-DIETER WELTMANN ${ }^{1}$ \\ ${ }^{1}$ Leibniz Institute for Plasma Science and Technology, INP Greifswald, Greifswald, Germany; \\ ${ }^{2}$ Greifswald University Medicine, Greifswald, Germany; \\ ${ }^{3}$ ZIK plasmatis at INP Greifswald, Greifswald, Germany
}

\begin{abstract}
Plasma medicine comprises the application of physical plasma directly on or in the human body for therapeutic purposes. Three most important basic plasma effects are relevant for medical applications: i) inactivation of a broad spectrum of microorganisms, including multidrugresistant pathogens, ii) stimulation of cell proliferation and angiogenesis with lower plasma treatment intensity, and iii) inactivation of cells by initialization of cell death with higher plasma treatment intensity, above all in cancer cells. Based on own published results as well as on monitoring of relevant literature the aim of this topical review is to summarize the state of the art in plasma medicine and connect it to redox biology. One of the most important results of basic research in plasma medicine is the insight that biological plasma effects are mainly mediated via reactive oxygen and nitrogen species influencing cellular redoxregulated processes. Plasma medicine can be considered a field of applied redox biology.
\end{abstract}

Plasma medicine is a new field of research combining plasma physics, life science and clinical medicine. Basically, medical application of physical plasma comprises two principal approaches: i) use of plasma-based or plasmasupplemented techniques to treat surfaces, materials or devices to realize specific qualities for subsequent special medical applications, and ii) direct application of physical plasma on or in the human (or animal) body to apply

This article is freely accessible online.

Correspondence to: Thomas von Woedtke, Leibniz Institute for Plasma Science and Technology (INP Greifswald), Felix-HausdorffStr. 2, 17489 Greifswald, Germany. Tel: +49 3834554445, e-mail: woedtke@inp-greifswald.de

Key Words: Plasma medicine, redox biology, cold atmospheric plasma (CAP), review. therapeutic effects based on direct interaction of plasma with living tissue. Plasma application for the treatment of medical materials or devices is an important subject of research and has been utilized for several years now (1-8). However, the core area of plasma medicine - as a new field of research focuses on the use of plasma technology in direct treatment of living cells and tissues. The aim of applied plasma medicine is to exploit a differentiated interaction of specific plasma components with specific structural, as well as functional elements or functionalities of living cells to control, and ideally, normalize therapeutic effects. Besides its antimicrobial activity, exposure of mammalian cells to physical plasma can lead either to stimulation or inhibition of cellular function (9). Consequently, most research and primary medical application of physical plasma is concentrated on wound healing and cancer treatment. During recent years, a broad spectrum of different plasma sources (called by many different names and abbreviations) has been designed and dedicated for biomedical applications (9-12).

\section{Plasma Generation and Plasma Sources for Biomedical Applications}

Physical plasma is a special excited gas state, sometimes named "the fourth state of matter" following solid, liquid, and gaseous states. It can be generated by a continuous supply of energy to the atoms or molecules of a neutral gas until an excited state is achieved. The energy required may be provided separately by thermal, chemical, electrical and radiative resources or a combination of all. However, the predominant ionizing mechanism is the collision process that involves inelastic collision, electron impact, radiative interactions and charge exchange. As the typical life span of excited states is about $10 \mathrm{~ns}$ stopping the energy supply starts a depletion process rapidly quenching the plasma. The electron impact ionization is the most robust procedure generating a plasma for biomedical purposes. The energy is transferred by inelastic and elastic collisions of high-energy 
electrons generated by a strong electric field with the atoms or molecules in the gas resulting in its partial ionization. The temperature of such partially ionized gas is always substantially lower than the characteristic ionization temperature. In a well-designed plasma source, ambient temperature of the plasma can be achieved. The physicochemical characteristics of plasma can be complex and they depend on a multitude of parameters, including the type and composition of the gas or gas mixture used for plasma generation, the applied energy and electrode configuration, the pressure, and the environment. Consequentially, a broad range of parameters can be controlled by the plasma source design. With regard to its application, especially in the medical context, useful classifications are thermal versus non-thermal plasmas and low pressure versus atmospheric pressure plasmas (13-15). For a direct application on living tissue as the main aim of plasma medicine, only plasma generated under atmospheric conditions should be used. Medical treatment techniques using such plasmas have been firmly established for a long time in the field of electro surgery, even if they were not explicitly referred to as plasma medicine at the time. Such techniques, like argon plasma coagulation (APC), rely on precisely targeted thermal necrotization of tissue to achieve hemostasis (cauterization), or to cut or remove tissue $(16,17)$. Furthermore, several plasma-based devices in cosmetics, e.g. for wrinkle removal and skin regeneration, also rely on thermal plasma effects $(18,19)$. Since the 1990s, technologies for stable and reproducible plasma generation at low temperature under atmospheric conditions are available on a larger scale, facilitating the generation of so-called cold atmospheric plasmas (CAP). This has led to considerable intensification of research in the field of medical applications of physical plasma at tissue-compatible temperatures. In terms of medical application, "cold" means temperatures lower than $40^{\circ} \mathrm{C}$ at the target site during plasma treatment (9).

Simplifying, generation of CAP and its components can be summarized with the following three steps $(9,11,14)$ :

i) Ionization and excitation of atoms or molecules of a neutral gas (argon, helium, oxygen, nitrogen, air, or mixtures thereof) via electron impact by supplying electrical energy;

ii) Interaction of electrons and high energy states of atoms or molecules with reaction partners in the plasma phase and its vicinity (ambient air, liquids, surfaces), generating secondary and tertiary reactive species;

iii) Emission of electromagnetic radiation (UV, visible light, IR/heat, electric fields) formed by excitation and depletion processes or charge transport.

It is important to note that the plasma state is maintained as long as the energy supply exists, i.e. it is not possible to store a plasma like a gas.

Because plasma contains highly motile electrons it is conductive and can transfer electrical current to cells and tissue with possible biological consequences (20). Also, the emitted electromagnetic radiation, above all the ultraviolet (UV) light, has the potential to elicit biological effects (21, 22). However, according to the current state of knowledge, free electrons, high energy states of atoms and molecules along with ions and radicals in the plasma and those generated in secondary reactions are the main components of the chemical reactivity and biological activity of a plasma (23). The sum of the CAP derived chemical entities is often circumscribed as reactive species.

A large number of plasma sources that are potentially useful for medical applications are described in the literature. They differ in their plasma generation mechanism, source geometry, working gases, and, consequently, vary in their application characteristics $(9,12,24-28)$. During recent years, mainly two fundamental concepts of CAP devices have been tested and are partially applied for medical purposes: i) dielectric barrier discharges (DBD) and ii) plasma jets $(9,29-32)$.

In Figure 1, three technical principles of plasma sources intended for biomedical applications are depicted $(11,30)$.

The volume DBD (Figure 1A) is characterized by plasma ignition in a gap between an isolated high voltage electrode and the target to be treated. Consequently, cultured cells or living tissues in biomedical application are part of the discharge electrode configuration. Plasma has a direct contact with the target to be treated and the target is directly exposed to the electrical field that is necessary for plasma generation $(9,31)$. In the surface DBD (Figure 1B), plasma is ignited around an individually designed electrode structure (e.g. circular or grid-like), which is isolated from a counter electrode. There is no direct contact of the active plasma with the target to be treated, instead impact is achieved by transport processes bringing the reactive species to the living tissue. With both DBD configurations, atmospheric air usually serves as the working gas for plasma generation. Both volume and surface DBD devices are suitable to generate plasmas over larger areas $(9,31)$. In a plasma jet device (Figure 1C), the electrode setup for plasma generation is located in or around a tube-like arrangement, in most cases inside a pen-like device. Diverse electrode configurations can be used, e.g. pin electrodes, ring electrodes, plate electrodes etc. The plasma is ignited inside the device using a working gas that is flowing through the tube. The so-called plasma effluent (or afterglow) is carried out along the gas flow and can be brought into direct contact with the target to be treated. In order to maintain a low temperature and to achieve excellent controllability of the discharge, most plasma jet devices are using noble gases (helium or argon) as working gas, often doped with small amounts of molecular gases (nitrogen, oxygen). The target to be treated is not part of the electrode configuration. However, because of the conductivity of the plasma and its afterglow, small 

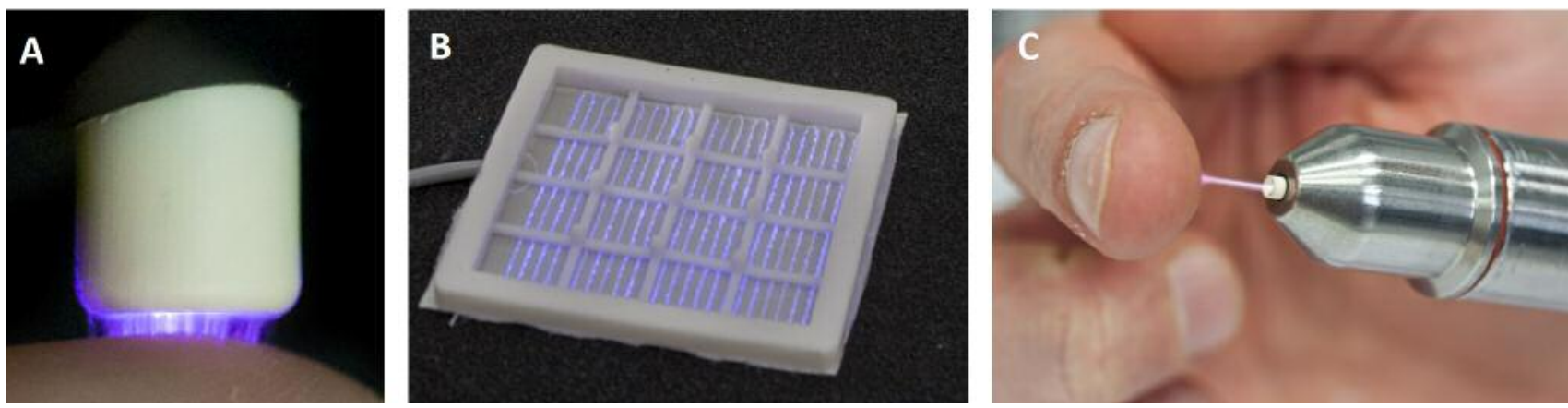

Figure 1. Example photographs of the most common cold atmospheric plasma source principles for biomedical applications: volume DBD (A), surface $D B D(B)$, and plasma jet $(C)$.

electrical currents may pass to the target. By choosing an appropriate design of electrode and high voltage waveform these currents can be easily controlled $(9,29,32)$.

One of the best-investigated plasma sources for biomedical application is the argon-driven cold atmospheric pressure plasma jet, kINPen (Figure 1C) (32-34). A needle electrode inside a dielectric capillary is powered with a sinusoidal high voltage $\left(2-6 \mathrm{kV}_{\mathrm{pp}}\right)$ with a frequency of $1.0-1.1 \mathrm{MHz}$ (power $<3.5 \mathrm{~W}$ in the hand-held unit). Argon gas with a flow rate of 3-5 standard liters per minute ( $\mathrm{s} / \mathrm{m})$ is used as the working gas. The plasma is generated at the tip of the needle and is subsequently released with the feed gas flow into the atmospheric environment, thereby generating a typical plasma effluent with a length of 9-12 $\mathrm{mm}$ and with $1 \mathrm{~mm}$ in diameter. Under these conditions, the electron density in the core plasma region near the high voltage electrode tip is in the order of $10^{12} \mathrm{~cm}^{-1}$ and one order of magnitude lower in the visible effluent zone. However, electron density depends on several parameters and can be varied by admixture of molecular gases, such as oxygen and nitrogen (32).

The reactive species generated inside the plasma or as a result of plasma interactions with the surrounding media are considered the most important components responsible for biological plasma effects. In the kINPen, the argon-based plasma effluent is exposed to atmospheric air containing predominantly oxygen, nitrogen, and water. Traces of these, especially the water, are contained in the working gas in low ppm-amounts, too. These atmospheric air compounds are the precursors for secondarily generated non-radical and radical reactive oxygen and nitrogen species (ROS, RNS). Generation of ROS and RNS can also be modulated by controlled admixture of oxygen, nitrogen, water or air to the argon working gas flow, or by gas shielding and modification of the atmosphere around the plasma effluent (32). When the effluent containing the ROS, RNS, and residual high energy states targets a liquid (a tissue), a number of transport processes and tertiary reactions with target molecules occurring is so far not fully understood. Current knowledge assumes that at the interface between gas phase and liquid (or solid) target as well as in the target bulk a considerable rearrangement of the ROS/RNS pattern occurs (Figure 2) (32, 35-38). Beside an interaction of the plasma derived species among themselves, the interaction with target biomolecules results in the formation of diverse chemical structures acting as a messenger or a beacon.

Because all plasma sources for biomedical applications are working under atmospheric air conditions or use ambient air as working gas, the generation of ROS and RNS from airbased oxygen and nitrogen is a corresponding feature of all these plasma sources. However, the composition and quantity of plasma-generated ROS and RNS, as well as UV irradiance, electrical field and other characteristics, are strongly dependent on specific plasma sources and device parameters as working gas composition, power input and temperature (39).

\section{Biological Plasma Effects and its Medical Use: Focus on Wound Healing}

Among the vast number of experimental reports on biological plasma effects (using different plasma sources and devices under varying conditions), three effects most important for a medical application are consistently reported (30):

i) Effective inactivation of a broad spectrum of microorganisms including multidrug-resistant pathogens;

ii) Stimulation of cell proliferation and angiogenesis with lower plasma treatment intensity and time;

iii) Initialization of (programmed) cell death with higher plasma treatment intensity and time, primarily in cancer cells.

With the improved availability of CAP technology in the 1990s, its antimicrobial activity was in the early focus of research with regard to microbial decontamination or sterilization of materials and devices $(40,41)$. Extensive 


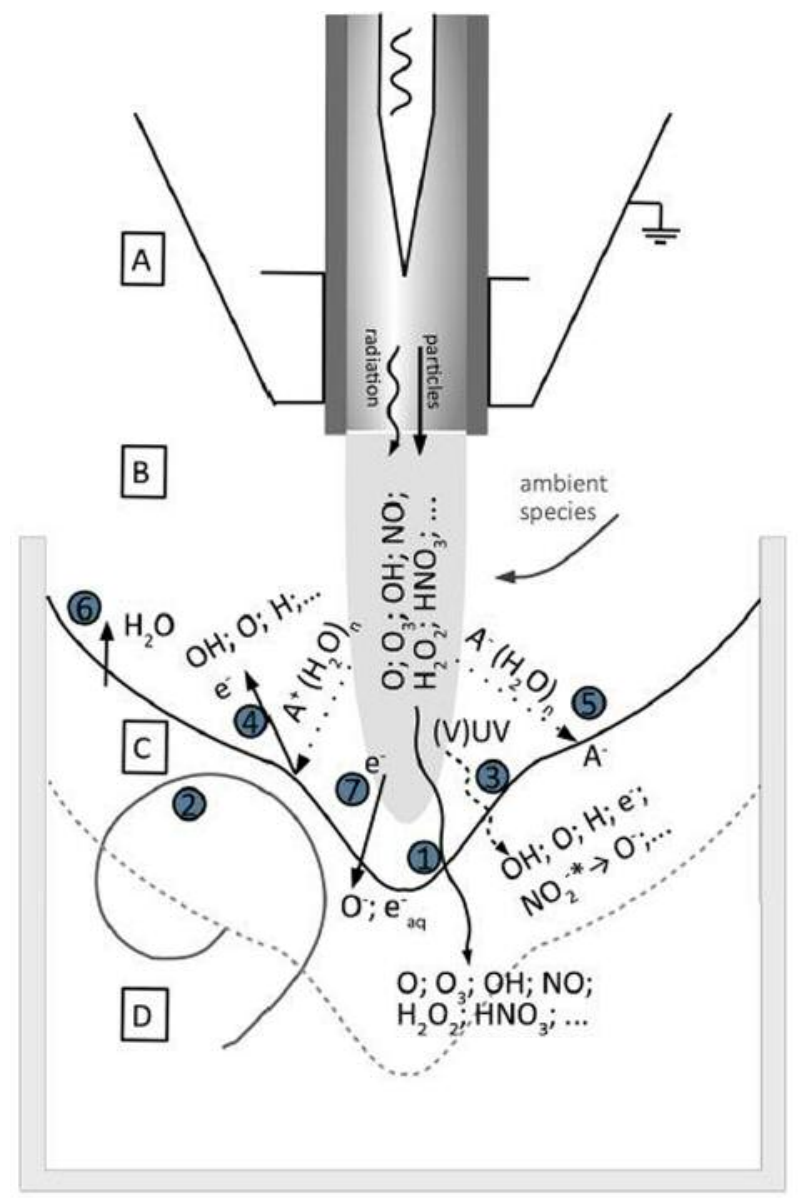

Figure 2. Schematic of interactions between the kINPen plasma effluent with aqueous liquid. There are four reaction regions: (A) core plasma region, $(B)$ effluent and plasma-ambient air interaction zone, $(C)$ plasma/gas/liquid interface, and (D) bulk liquid. Seven processes are dominant for the generation of ROS and RNS, and their transfer: (1), (2) mass transfer from plasma to liquid based on gas/plasma component dissolution and gas and liquid flow, respectively, (3) photolysis based on the plasma UV radiation, (4); positive ions and clusters, which induce sputtering processes releasing water, gases, or electrons from the liquid, (5) negative ions, clusters, and cluster transport, (6) water evaporation, and (7) electron impact or transport. (Adapted from 32).

research has been done on the mechanisms of low-pressure cold plasma interaction with microorganisms. This was mainly attributed to UV-based DNA damage in combination with erosion of microorganism structures by UV-based photodesorption and etching processes by reactive plasma species (42-45). However, the knowledge on mechanisms of inactivation of microorganisms by CAP is limited. Microbicidal CAP effects are mainly attributed to the activity of ROS and RNS leading to oxidative damage and modification of cytoplasmatic membrane, proteins, and DNA (46-48). Furthermore, induction of apoptosis-like processes of programmed cell death in bacteria is being discussed as a potential mechanism (49). Other physical mechanisms are currently under investigation, for instance electrostatic disruption by plasma-derived charged particles, or electroporation caused by plasma-related electric fields $(49,50)$.

Regardless of the specific mode of action, early experimental evidence on microbicidal plasma effects on heat or radiation-sensitive material surfaces spurred further efforts to investigate plasma effects on contaminated or infected tissue. Several in vitro studies on effective inactivation of clinically relevant microorganisms and viruses have produced promising results (51-58). The first clinical investigations on antiseptic plasma effects on tissue and wounds that followed have shown rather modest microbial reduction rates (59-63). However, improvement of wound healing in general has been partially seen during these clinical investigations $(61,64)$. Some additional case reports and clinical investigations with different plasma devices support these findings $(65,66)$.

Starting in 2013, the first cold atmospheric pressure plasma devices received CE certification as medical devices for the purpose of treating chronic wounds as well as pathogen-based skin diseases in Germany and Europe. These include the argon-driven, jet-like CAP devices kINPen MED (neoplas tools GmbH Greifswald, Germany) and SteriPlas (ADTEC, Hunslow, UK) as well as the DBD-based devices PlasmaDerm (CINOGY GmbH Duderstadt, Germany) and plasma care (terraplasma medical GmbH Garching, Germany), the latter two using atmospheric air as working gas. Certification of all these devices was based on comprehensive physical and biological characterization of the respective plasma source accompanied with clinical investigations $(9,10,25,34,53,55,59-64)$. However, even if randomized controlled clinical trials are not available as yet (as unfortunately is the case for many wound therapies due to a lack of standardization in wound scoring), positive experiences are consistently reported from the medical practice. Particularly in chronic wounds, e.g. venous leg ulcers where any conventional therapeutic options have been exhausted, a clear benefit of CAP treatment has been found. Some practitioners have reported a re-start or acceleration of wound healing process in more than $80 \%$ of cases as a preliminary result, particularly following the use of the kINPen MED $(11,30)$. Now, the most important aim is to validate these results by systematic clinical data.

These clinical experiences confirm a very early hypothesis in plasma medicine research, that plasma effects on wound healing may be a result of a two-step activity: antiseptics on wound surface in combination with stimulation of tissue regeneration (67). Several experimental in vitro studies could demonstrate a direct impact of CAP on cell proliferation and migration as well as on angiogenesis (68-76). The stimulating effect on skin tissue regeneration was confirmed 
in several in vivo animal experiments $(69,74-90)$ and in human volunteers or patients with reasonably defined wounds (91-93). It has to be pointed out that these lastmentioned wound healing effects in vivo were demonstrated in acute wounds without any interfering microbial contamination. With plasma treatment, the spontaneous wound healing process was not impeded, and there was an acceleration in the early stage of wound healing. With this direct proof of stimulation of wound healing by plasma treatment, it seems that the antiseptic plasma effect can be partially pushed into the background because it may turn out that it is not the dominating process as it was assumed for several years. Consequently, as a next step in clinical research, it should be investigated, if this early stimulation of wound healing may have any beneficial effects also in acute wounds, e.g. with regard to scar formation or prevention of complications in wound healing. Possible fields of application of CAP in acute wound healing could be in patients with co-morbidities leading to a high risk of disturbed wound healing and subsequent chronification, in the case of large-area burns or in the treatment of skin graft donor and acceptor sites $(92,94)$.

Nevertheless, there should be no doubt that plasma-induced antiseptics have an important additional effect in the case of contaminated wounds. Here, a very important question is why plasma is destructive or inactivating for microorganisms while stimulating repair mechanisms on mammalian cells. There is some evidence that the ROS-RNS composition resulting from plasma generation under atmospheric air conditions is more toxic for microorganisms because both oxygen- and nitrogencontaining reactive species are required for antimicrobial effects, whereas mammalian cell toxicity is mostly dependent on oxygen-based reactive species (95). Another very interesting insight is that, because of the role of ROS generated by immune cells to fight wound infection, wounded tissue takes cytoprotective measures to promote some tissue "resilience" for protection against ROS caused damage (96). This physiological mechanism may also be protective against plasma-generated ROS and RNS.

\section{Redox Biology as the Scientific Grounding of Plasma Medicine}

The fact that the biological effects of CAPs are mainly based on ROS and RNS, was primarily reasoned from experimental observations in vitro. Plasma effects on mammalian cells were found to be dependent on cell culture media composition, each exhibiting a different antioxidative potential. Additionally, biological plasma effects could be extinguished when antioxidants like N-Acetylcystein (NAC) were added (97-99). A multitude of investigations on plasmaliquid interactions has demonstrated the occurrence of ROS and RNS in liquid phases following plasma treatment (36,
37). Moreover, it has been shown several times that liquids, such as water, physiological saline, or cell culture media become biologically effective following plasma treatment (100-105). This underlines a key role of liquid phase composition for biological plasma effects. ROS and RNS like superoxide $\left(\mathrm{O}_{2}^{-} \bullet\right)$, hydrogen peroxide $\left(\mathrm{H}_{2} \mathrm{O}_{2}\right)$, hydroxyl radical $(\bullet \mathrm{OH})$, singlet oxygen $\left({ }^{1} \mathrm{O}_{2}\right)$, ozone $\left(\mathrm{O}_{3}\right)$, and RNS, such as nitric oxide $(\bullet \mathrm{NO})$, nitrogen dioxide $\left(\bullet \mathrm{NO}_{2}\right)$ and peroxynitrite (ONOO-), are transferred from plasma into the liquid environment of cells and tissue, or they are generated by a very complex network of secondary liquid reactions (Figure 2) (23, 106-111).

This insight of the central role of ROS and RNS has opened up the door to the field of redox biology to explain and interpret biological effects caused by CAP. Redox biology can be taken as the interface between the more or less unspecific impact of external factors and the specific response and adaptation of a cell or an organism via its metabolic and macromolecular structures (112). Meanwhile, it is well known that ROS and RNS are not solely harmful in cells, but also serve as signaling molecules via reversible oxidations and reductions of specific protein structures with cysteine as a major reaction target (113). In a comprehensive in vitro study using different jet-based plasma devices with different working gas mixtures, the cysteine-oriented plasma chemistry could be proven. Furthermore, it could be demonstrated that cysteine is a useful and sensitive tracer compound to discriminate between the chemical potential of different plasma sources or gas mixtures, respectively (114).

One of the most important players for ROS and RNSbased regulation in cell physiology is the mammalian Kelchlike ECH-associated protein 1 (Keap1)-nuclear factor erythroid 2-related factor (Nrf2) pathway. In regular cell physiology, it uses cysteine oxidation to respond to increased ROS levels. By redox modification of cysteine-residues of Keap1, Nrf2 is released from its complex and the E3 ubiquitin ligase cullin 3 (CUL3). Subsequently, Nrf2 translocates from the cytosol to the nucleus where it binds to antioxidant responsive elements (ARE) on DNA, promoting the upregulation of antioxidant genes $(113,115)$. It has been demonstrated that CAP treatment of human keratinocytes in vitro leads to the stimulation of this Nrf2 pathway, resulting in the translocation of Nrf2 into the nucleus and the subsequent activation of Nrf2-ARE-targets, such as glutathione (GSH), glutathione reductase (GSR), glutathione S-transferase (GST), superoxide dismutase (SOD), heme oxygenase 1 (HMOX-1), and NADPH quinine oxidoreductase 1 (NQO1) $(90,116)$. Moreover, in an acute wound healing study in mice, an early activation of the Nrf2 pathway has also been demonstrated in vivo and ex vivo on skin tissue, dermal fibroblasts and epidermal keratinocytes (Figure 3) $(76,117)$. 
A

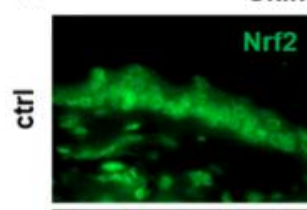

Skin tissue
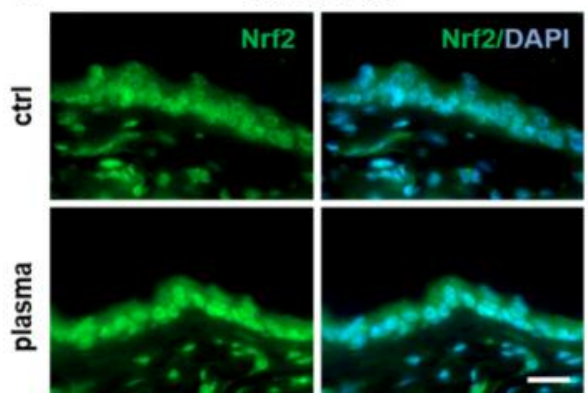

B

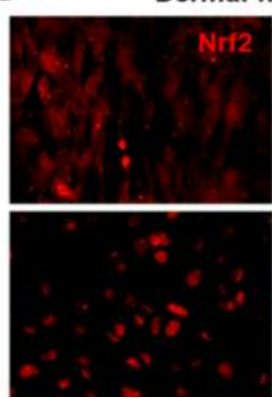

Dermal fibroblasts

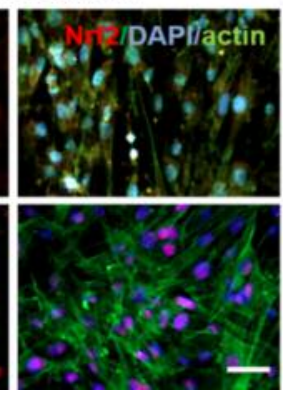

C

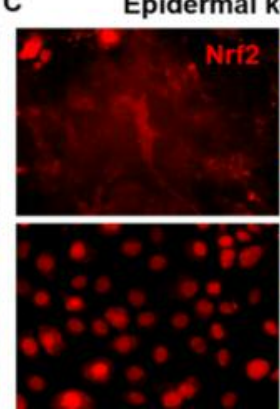

Epidermal keratinocytes

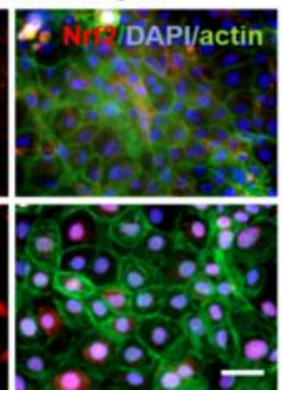

Figure 3. CAP treatment induces an early translocation of Nrf2 from the cytoplasm to the nucleus (lower images) in skin tissues (A, 3 s CAP treatment), dermal fibroblasts ( $B, 60 \mathrm{~s} C A P$ treatment) and in epidermal keratinocytes $(C, 60 \mathrm{~s} C A P$ treatment) in contrast to untreated controls (upper images). Immunofluorescent staining of nuclei (blue: DAPI - 4',6-Diamidino-2-phenylindole), Nrf2 (green in A, red in B, C), and F-actin cytoskeleton (green in B, C: Phalloidin-FITC). Scale bars $=100 \mu \mathrm{m}$ (See 117 for experimental details).

This Nrf2 pathway stimulation by CAP treatment seems to be one of the most important mechanisms to protect mammalian cells from genotoxic plasma effects. Indeed, a huge number of in vitro studies report on potential genotoxic CAP effects on isolated, naked, or cellular DNA (118). However, several investigations of potential genotoxic effects of CAP by in vitro standard procedures for mutagenicity testing of chemical substances has demonstrated no extended mutation rate of plasma treated cells (119-123). The main conclusion is that CAP treatment causes no enhanced genotoxic risk. This has also been confirmed in an animal study using hairless immunocompetent mice (124), in CAPtreated skin biopsies (125-127), and in clinical follow-up investigations of plasma-treated wounds $(128,129)$.

Meanwhile, it is well known that ROS and RNS also play an important role as secondary messengers in the orchestration of wound healing processes $(130,131)$. This idea of redox-based repair of destroyed tissue becomes important in connection with acute and chronic wound healing supported by CAP. There is some evidence that the Nrf2 pathway does not only function in cellular defense against increased ROS levels but it also has central regulatory effects in wound healing (Figure 4) $(117,132)$.

The schematic overview in Figure 4 summarizes the state of knowledge on molecular patterns in wound healing in response to CAP treatment and aligns these results with insights from redox biology and research on molecular biology of healing processes in acute wounds $(90,117,124$, 132). Briefly, it is assumed that CAP treatment leads to a transient and reversible modification of proteins and the lipid bilayer, which contribute to normal or pathologic stages of wound healing $(117,140,141)$. This is crucially mediated by the Nrf2 pathway $(90,116,117)$. Its key role in up-regulation of detoxifying and antioxidant genes is mentioned above (113, 115). Moreover, via activation of Keap1, which does not only act as sensing element in the redox stress reaction of the Nrf2 pathway, CAP stabilizes the architecture of F-actin cytoskeleton and focal adhesions, and increases granulation tissue formation and matrix deposition $(117,132)$. As a key regulator in macrophages, Nrf2 mediates the infiltration of macrophages and neutrophils and the upregulation and secretion of pro- and anti-inflammatory ligands (e.g. TNF $\alpha$, TGF $\beta$, IL-1 $\beta$ etc.), which activate signaling and intracellular generation of reactive oxygen and nitrogen species (117).

Furthermore, CAP supports angiogenesis by recruiting endothelial cells, stimulates growth factor expression like keratinocyte growth factor (KGF), epidermal growth factor (EGF), or vascular epidermal growth factor (VEGF), and activates protein kinase $\mathrm{B}$ (Akt), which induces $\mathrm{Nrf} 2$ expression $(70,71,138,139)$. Nrf2-regulated inflammation and angiogenesis is also shown in numerous studies (133137). Appropriate effects of CAP are also attributed to the regulation of $\operatorname{Nrf} 2(90,116,117)$.

Moreover, the activity of the transcription factor p53 depends on the stage of wound healing and reactive species concentration $(90,117)$. The tumor suppressor protein $\mathrm{p} 53$ influences cell proliferation and apoptosis and has a central role in angiogenesis and cell cycle regulation and DNA repair. When the expression of p53 is relatively low, p53 enhances the protein level of Nrf2 and its target genes promote cell survival depending on the cyclin-dependent kinase inhibitor 1 (p21). When p53 expression is high, the Nrf2-mediated survival response is inhibited by p53 $(142,143)$.

Taken together, CAP treatment leads to an accelerated repair in acute wounds. All these findings are mainly based on numerous in vitro and in vivo studies using the argondriven cold atmospheric plasma jet kINPen $(32,34)$.

The long-term and systematic investigation of molecular biological processes of plasma-supplemented wound healing processes has opened several interconnections of plasma 


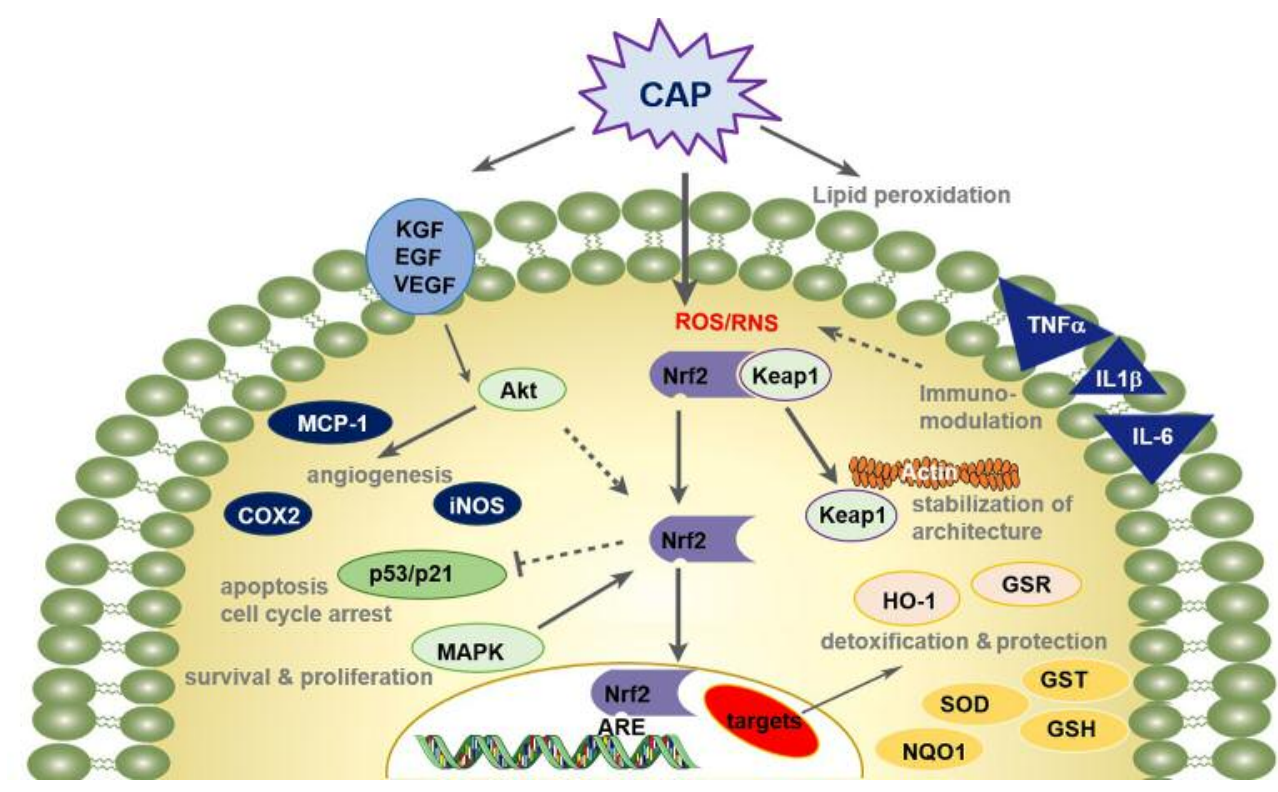

Figure 4. CAP treatment improves wound healing processes via redox-regulated pathways. Enhanced wound healing by CAP involves a distinct temporal pattern of inflammation, a promoting of pro-angiogenetic factors, and a balance of cellular proliferation and apoptotic events. The cellular redox homeostasis is maintained and cells are defended from damage by a strong modulation of the nuclear E2-related factor (Nrf2) pathway.

medicine and redox biology. In wound healing, insights from redox biology, indicating that redox-sensitive processes are driving factors in tissue repair $(130,131)$, can serve as a sound scientific basis to confirm CAP applications in this field. There is no doubt that this may be true also for other fields of biomedical application of cold atmospheric plasma.

\section{Medical Application of Physical Plasma - Present and Future}

Besides wound healing, several other indications for plasma application in dermatology are being taken into consideration, mainly in the treatment of pathogen-based and/or inflammatory skin irritations and diseases $(128,144$ 146). Also, anti-infective plasma applications have been tested in ophthalmology (147-149), while plasma in dentistry is under research for several years, too. Possible dental applications include antimicrobial plasma activity, inactivation and removal of biofilm on teeth and on dental implants, disinfection of tooth root canal, plasma-assisted cleaning and optimization of tooth and implant surfaces to improve bone integration. Additionally, in-growth or bonding of dental fillings and prostheses, decontamination and coating of dental prosthesis, antimicrobial treatment of the oral mucosa, oral wound healing and tooth whitening are under investigation (150). For more details on promising clinical applications of CAP, see a recent review by Metelmann et al. (151).
As it was mentioned above, depending on plasma treatment intensity and time, it is possible to inactivate mammalian cells by initializing programmed cell death in them. This is true particularly for cancer cells. After several reports on apoptosis induction in cancer cells in vitro (152-155), animal studies on transcutaneous plasma treatment of subcutaneously induced solid tumors could prove the general concept of plasmasupported tumor treatment $(156,157)$. However, there are several open questions about the mechanisms of plasma attack on cancer cells, a possible selectivity with regard to healthy tissue or on possible secondary effects distant from the region of local plasma treatment. Most current hypotheses are based on a predominant role of plasma-generated redox active species (158). Briefly, it is assumed that CAP treatment causes apoptosis of cancer cells through a selective rise of intracellular ROS and corresponding ROS-based death pathways. In that regard, enhanced sensitivity of cancer cells may be caused by enhanced ROS levels in the cancer resulting from its unique metabolic activities $(113,159)$. Other hypotheses attribute differences in cell sensitivity to significant variations of aquaporins (AQPs) among different cell lines. Enhanced generation of long-lived species, such as $\mathrm{H}_{2} \mathrm{O}_{2}$ via extracellular superoxide dismutase (Ex-SOD, SOD3) on the cytoplasmatic membrane of cancer cells and a subsequent trigger of immune attack on tumoral tissues via $\mathrm{H}_{2} \mathrm{O}_{2}$-mediated (second messenger) lymphocyte activation is also discussed $(160,161)$. Another interesting hypothesis is based on the specific action of CAP via singlet oxygen $\left({ }^{1} \mathrm{O}_{2}\right)$ generation and the subsequent 


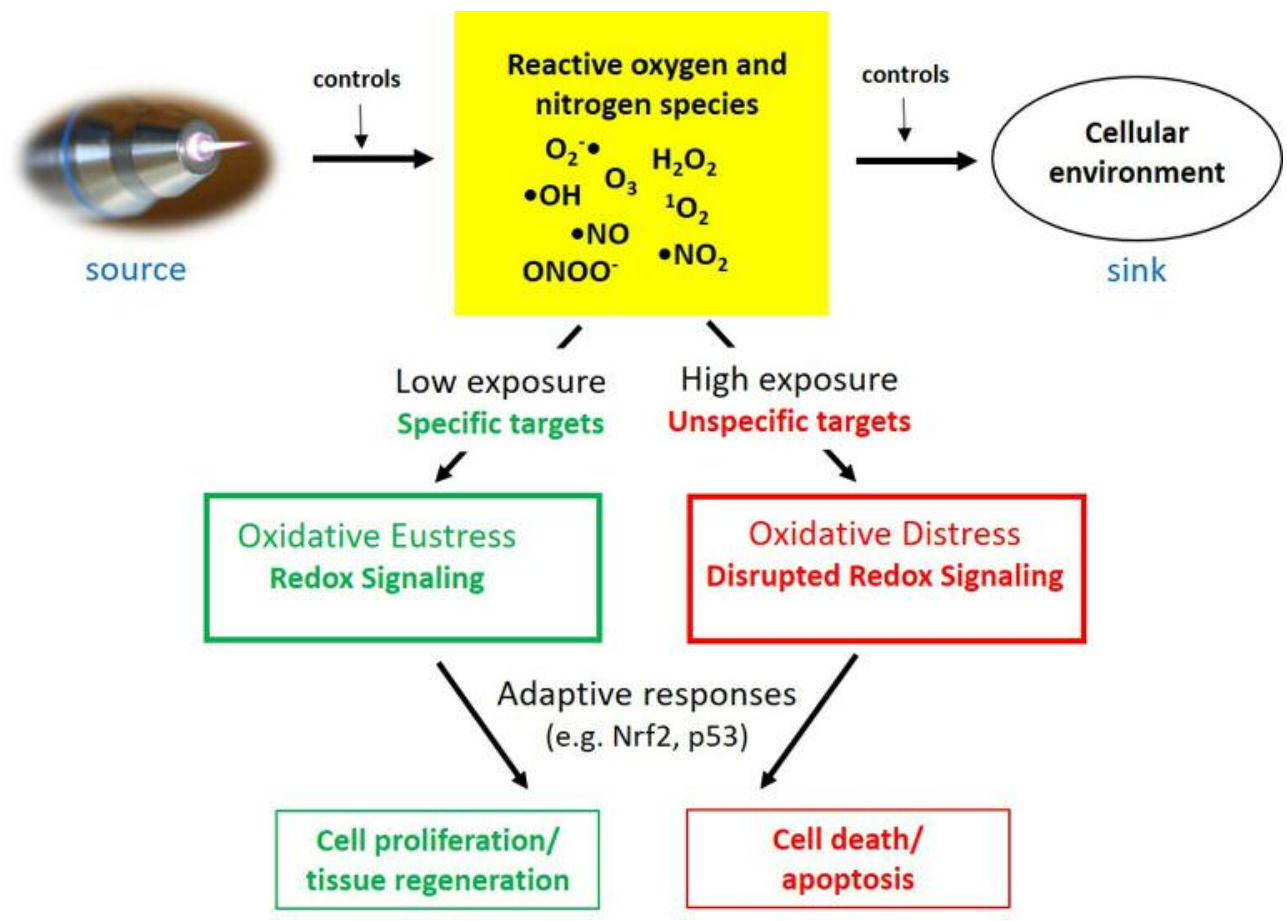

Figure 5. Different aspects of CAP-triggered oxidative stress, its control, adaptive response and physiological consequences. (Adapted from176).

induction of intercellular ROS-RNS-dependent apoptosisinducing signaling (162). Finally, a plasma-induced stimulation of immunogenic cell death via damage associated molecular patterns (DAMPs) is under discussion $(163,164)$.

There are several promising experimental results leading to the situation that plasma application in cancer therapy is now one of the most attractive research fields in plasma medicine (155). Based on the experimental proof of inactivation of single layers of cancer cells by local plasma treatment (165), first of all a supportive plasma application in combination with surgical tumor resections in cases where large-scale tumor removal is impossible, seems to be realistic $(166,167)$. Moreover, first CAP applications in palliative care in patients with advanced squamous cell carcinoma of head and neck have not only resulted in the intended reduction of microbial load and resulting reduction of typical fetid odor, but in some particular cases also in transient tumor remission (168-170). Further research will tell us if any direct plasma application is useful for the reduction or complete removal of solid tumors and will lead to a "paradigm shift in cancer therapy" as it was predicted some years ago (156).

\section{Conclusion and Outlook}

It is a very interesting perspective to attribute vital processes to electron flow, i.e. energetic electrons are processed by biochemical and molecular biological pathways to transfer their energy into chemical energy to realize metabolic and signaling processes. From this point of view, redox gradients are eventually the driving forces of life (171). Because the primary process of generation of cold atmospheric plasma is the acceleration of electrons by electrical fields, plasma application may be considered as an initial part of a complex electron-transfer process transferring electrical energy via complex chemical reaction cascades into biological effects.

One of the main advantages of biomedical application of CAP is that the active components, such as ROS and RNS, are generated locally and only for the required duration of the application primarily by a physical process. By means of variations of several plasma parameters, the essential ROS and RNS-based energy transfer from plasma to cells and tissue can be easily controlled. This is the main reason why one can describe the biomedical plasma application as a field of applied redox biology.

The insight that CAP impact may result either in cell and tissue stimulation or in cell death, depending on exposure conditions (e.g. treatment time), fits very well with the theory of oxidative stress mainly introduced and developed by Sies (172-176). According to that, oxidative stress can be differentiated between oxidative eustress and oxidative distress depending on low or high oxidant exposure. These processes are strongly controlled by adaptive cellular 
responses, including the Nrf2 pathway that plays a central role above all in cell defence $(115,176,177)$.

While CAP serves as a controllable source of redoxactive species, the cellular environment and its antioxidative capacity may act as a "ROS-RNS sink". The interaction of both components will define the degree of exposure of the living system to redox active species. Depending on the cellular ability of adaptive response as a third component in this process, either oxidative eustress or distress is resulting. In the case of CAP treatment this may result in stimulation of tissue regeneration or cell death (Figure 5).

Based on these insights, redox biology will not only serve as a scientific basis to further explain biological plasma effects. Conversely, CAP may become a useful tool for specific research in redox biology. It is obvious that both plasma medicine and redox biology are interested in similar questions:

i) Are there single and specific ROS and RNS responsible for distinct biological effects or is it only a matter of redox potential at the cellular target sites?

ii) How to identify and analyze specific ROS and RNS at their site of action?

iii) Which cell biological mechanisms are responsible for different sensitivity of several cell types to the impact of CAP as well as redox-active species?

iv) Is it possible to find a measure for biological plasma effects that can serve as a kind of "treatment dose"?

This preliminary small catalogue of questions can be easily extended considering the findings and future prospects of redox biology, both in view of basic research and with respect to specific pathologies (178). Finally, yet importantly, the concept of oxidative eustress and distress and its possible controllability by CAP treatment can also serve for further basic research on the "hormesis" phenomenon, which has received increased attention in recent years $(176,179-182)$.

\section{Conflicts of Interest}

The majority of research work that served as a scientific basis for further development and CE certification of the atmospheric pressure plasma jet kINPen MED as a medical device by neoplas tools GmbH Greifswald, Germany has been realized by INP Greifswald. INP Greifswald is a minority shareholder of neoplas tools GmbH Greifswald, Germany.

\section{Authors' Contributions}

ThvW was responsible for the concept of the manuscript, review of literature and writing of the text in general. AS, SB and KW contributed detailed content on mechanisms on CAP-supported wound healing, cellular redox mechanisms, and plasma chemistry, respectively. AS compiled and designed Figure 4. All authors reviewed the manuscript.

\section{Acknowledgements}

The authors acknowledge stimulating discussions on redox biology and their significance for plasma medicine with David Graves, UC Berkeley, USA, and Georg Bauer, Medical Center - University of Freiburg, Germany. The German Federal Ministry of Education and Research financially supports basic research on plasma medicine at INP Greifswald (grant numbers 03Z22DN11\&12). Plasma medicine research at INP Greifswald is part of the Research Alliance "Leibniz Health Technologies".

\section{References}

1 Favia P and d'Agostino R: Plasma treatments and plasma deposition of polymers for biomedical application. Surf Coat Technol 98: 1102-1106, 1998. DOI: 10.1016/S0257-8972(97) 00285-5

2 Ohl A and Schröder K: Plasma-induced chemical micropatterning for cell culturing applications: a brief review. Surf Coat Technol 116-119: 820-830, 1999. DOI: 10.1016/S0257-8972(99)00150-4

3 d'Agostino R, Favia P, Oehr C and Wertheimer MR: LowTemperature Plasma Processing of Materials: Past, Present, and Future. Plasma Process Polym 2: 7-15, 2005. DOI: 10.1002/ ppap.200400074

4 Desmet T, Morent R, De Geyter N, Leys C, Schacht E and Dubruel P: Nonthermal Plasma Technology as a Versatile Strategy for Polymeric Biomaterials Surface Modification: A Review. Biomacromolecules 10: 2351-2378, 2009. PMID: 19655722. DOI: $10.1021 / \mathrm{bm} 900186 \mathrm{~s}$

5 Bazaka K, Jacob MV, Crawford RJ and Ivanova EP: Plasmaassisted surface modification of organic biopolymers to prevent bacterial attachment. Acta Biomater 7: 2015-2028, 2011. PMID: 21194574. DOI: 10.1016/j.actbio.2010.12.024

6 Nikiforov A, Deng X, Xiong Q, Cvelbar U, DeGeyter N, Morent R and Leys C: Non-thermal plasma technology for the development of antimicrobial surfaces: a review. J Phys D Appl Phys 49: 204002, 2016. DOI: 10.1088/0022-3727/49/20/204002

7 Fiebrandt M, Lackmann J-W and Stapelmann K: From patent to product? 50 years of low-pressure plasma sterilization. Plasma Process Polym 15: e1800139, 2018. DOI: 10.1002/ ppap.201800139

8 Bekeschus S, Favia P, Robert E and von Woedtke Th: White paper on plasma for medicine and hygiene: Future in plasma health sciences. Plasma Process Polym 16: e1800033, 2019. DOI: 10.1002/ppap.201800033

9 von Woedtke Th, Reuter S, Masur K and Weltmann K-D: Plasmas for medicine. Phys Rep 530: 291-320, 2013. DOI: 10.1016/j.physrep.2013.05.005

10 Isbary G, Shimizu T, Li Y-F, Stolz W, Thomas HM, Morfill GE and Zimmermann JL: Cold atmospheric plasma devices for medical issues. Expert Rev Med Devic 10: 367-377, 2013. PMID: 23668708. DOI: 10.1586/erd.13.4

11 Weltmann K-D and von Woedtke Th: Plasma Medicine - current state of research and medical application. Plasma Phys Control Fusion 59: 014031, 2017. DOI: 10.1088/0741-3335/59/ 1/014031

12 Tanaka H, Ishikawa K, Mizuno M, Toyokuni S, Kajiyama H, Kikkawa F, Metelmann H-R and Hori M: State of the art in medical applications using non-thermal atmospheric pressure plasma. Rev Mod Plasma Phys 1: 3, 2017. DOI: 10.1007/s4161 4-017-0004-3 
13 Braithwaite NStJ: Introduction to gas discharges. Plasma Sources Sci Technol 9: 517-527, 2000. DOI: 10.1088/09630252/9/4/307

14 Conrads H and Schmidt M: Plasma generation and plasma sources. Plasma Sources Sci Technol 9: 441-454, 2000. DOI: 10.1088/0963-0252/9/4/301

15 Bogaerts A, Neyts E, Gijbels R and van der Mullen J: Gas discharge plasmas and their applications. Spectrochim Acta B 57: 609-658, 2002. DOI: 10.1016/S0584-8547(01)00406-2

16 Canady J, Wiley K and Ravo B: Argon Plasma Coagulation and the Future Applications for Dual-Mode Endoscopic Probes. Rev Gastroenterol Disord 6: 1-12, 2006. PMID: 16520707.

17 Raiser J and Zenker M: Argon plasma coagulation for open surgical and endoscopic applications: state of the art. J Phys D Appl Phys 39: 3520-3523, 2006. DOI: 10.1088/0022-3727/39/ $16 / \mathrm{S} 10$

18 Foster KW, Moy RL and Fincher EF: Advances in plasma skin regeneration. J Cosmet Dermatol 7: 169-179, 2008. PMID: 18789051. DOI: 10.1111/j.1473-2165.2008.00385.x

19 Bentkover SH: Plasma Skin Resurfacing: Personal Experience and Long-Term Results. Facial Plast Surg Clin North America 20: 145-162, 2012. PMID: 22537783. DOI: 10.1016/j.fsc. 2012.02 .010

20 McCaig CD, Rajnicek AM, Song B and Zhao M: Controlling Cell Behavior Electrically: Current Views and Future Potential. Physiol Rev 85: 943-978, 2005. PMID: 15987799. DOI: 10.1152/physrev.00020.2004

21 Sinha RP and Häder D-P: UV-induced DNA damage and repair: a review. Photochem Photobiol Sci 1: 225-236, 2002. PMID: 12661961.

22 Sklar LR, Almutawa F, Lim HW and Hamzavi I: Effects of ultraviolet radiation, visible light, and infrared radiation on erythema and pigmentation: A review. Photochem Photobiol Sci 12: 54-64, 2013. PMID: 23111621. DOI: 10.1039/c2pp25152c

23 Graves DB: The emerging role of reactive oxygen and nitrogen species in redox biology and some implications for plasma applications to medicine and biology. J Phys D Appl Phys 45: 263001, 2012. DOI: 10.1088/0022-3727/45/26/263001

24 Weltmann KD, Kindel E, von Woedtke Th, Hähnel M, Stieber $\mathrm{M}$ and Brandenburg R: Atmospheric-pressure plasma sources: Prospective tools for plasma medicine. Pure Appl Chem 82: 1223-1237, 2010. DOI: 10.1351/PAC-CON-09-10-35

25 Weltmann KD and von Woedtke Th: Basic requirements for plasma sources in medicine. Eur Phys J-Appl Phys 55: 13807, 2011. DOI: $10.1051 /$ epjap/2011100452

26 Park GY, Park SJ, Choi MY, Koo IG, Byun JH, Hong JW, Sim JY, Collins GJ and Lee JK: Atmospheric-pressure plasma sources for biomedical applications. Plasma Sources Sci Technol 21: 043001, 2012. DOI: 10.1088/0963-0252/21/4/ 043001

27 Setsuhara Y: Low-temperature atmospheric-pressure plasma sources for plasma medicine. Arch Biochem Biophys 605: 310, 2016. PMID: 27109191. DOI: 10.1016/j.abb.2016.04.009

28 Laroussi M, Lu X and Keidar M: Perspective: The physics, diagnostics, and applications of atmospheric pressure low temperature plasma sources used in plasma medicine. J Appl Phys 122: 020901, 2017. DOI: 10.1063/1.4993710

29 Winter J, Brandenburg R and Weltmann K-D: Atmospheric pressure plasma jets: an overview of devices and new directions. Plasma Sources Sci Technol 24: 064001, 2015. DOI: 10.1088/0963-0252/24/6/064001
30 Weltmann K-D, Metelmann H-R and von Woedtke Th: Low temperature plasma applications in medicine. Europhysics News (EPN) 47(5-6): 39-42, 2016. DOI: 10.1051/epn/2016507

31 Brandenburg R: Dielectric barrier discharges: progress on plasma sources and on the understanding of regimes and single filaments. Plasma Sources Sci Technol 26: 053001, 2017. DOI: 10.1088/1361-6595/aaced9

32 Reuter S, von Woedtke Th and Weltmann K-D: The kINPen a review on physics and chemistry of the atmospheric pressure plasma jet and its applications. J Phys D Appl Phys 51: 233001, 2018. DOI: 10.1088/1361-6463/aab3ad

33. Weltmann K-D, Kindel E, Brandenburg R, Meyer C, Bussiahn $\mathrm{R}$, Wilke $\mathrm{C}$ and von Woedtke Th: Atmospheric Pressure Plasma Jet for Medical Therapy: Plasma Parameters and Risk Estimation. Contrib Plasma Phys 49: 631-640, 2009. DOI: 10.1002/ctpp.200910067

34 Bekeschus S, Schmidt A, Weltmann K-D and von Woedtke Th: The plasma jet kINPen - A powerful tool for wound healing. Clin Plasma Med 4: 19-28, 2016. DOI: 10.1016/j.cpme.2016.01.001

35 Bruggeman $\mathrm{P}$ and Leys C: Non-thermal plasmas in and in contact with liquids. J Phys D Appl Phys 42: 53001, 2009. DOI: $10.1088 / 0022-3727 / 42 / 5 / 053001$

36 Jablonowski $\mathrm{H}$ and von Woedtke Th: Research on plasma medicine-relevant plasma-liquid interaction: What happened in the past five years? Clin Plasma Med 3: 42-52, 2015. DOI: 10.1016/j.cpme.2015.11.003

37 Bruggeman PJ, Kushner MJ, Locke BR, Gardeniers JGE, Graham WG et al: Plasma-liquid interactions: a review and roadmap. Plasma Sources Sci Technol 25: 053002, 2016. DOI: 10.1088/0963-0252/25/5/053002

38 Vanraes $\mathrm{P}$ and Bogaerts A: Plasma physics of liquids - A focused review. Appl Phys Rev 5: 031103, 2018. DOI: $10.1063 / 1.5020511$

39 Lu X, Naidis GV, Laroussi M, Reuter S, Graves DB and Ostrikov K: Reactive species in non-equilibrium atmosphericpressure plasmas: Generation, transport, and biological effects. Phys Rep 630: 1-84, 2016. DOI: 10.1016/j.physrep.2016.03.003

40 Laroussi M: Sterilization of contaminated matter with an atmospheric pressure plasma. IEEE Trans Plasma Sci 24: 11881191, 1996. DOI: $10.1109 / 27.533129$

41 Ehlbeck J, Schnabel U, Polak M, Winter J, von Woedtke Th, Brandenburg R, von dem Hagen T and Weltmann K-D: Low Temperature Atmospheric Pressure Plasma Sources for Microbial Decontamination. J Phys D Appl Phys 44: 013002, 2011. DOI: $10.1088 / 0022-3727 / 44 / 1 / 013002$

42 Moisan M, Barbeau J, Moreau S, Pelletier J, Tabrizian M and Yahia L'H: Low-temperature sterilization using gas plasmas: a review of the experiments and an analysis of the inactivation mechanisms. Int J Pharm 226: 1-21, 2001. PMID: 11532565. DOI: $10.1016 / \mathrm{S} 0378-5173(01) 00752-9$

43 Moisan M, Barbeau J, Crevier M-C, Pelletier J, Philip N and Saoudi B: Plasma sterilization. Methods and mechanisms. Pure Appl Chem 74: 349-358, 2002. DOI: 10.1351/pac200274 030349

44 Laroussi M: Low temperature plasma-based sterilization: overview and state-of-the-art. Plasma Process Polym 2: 391400, 2005. DOI: $10.1002 /$ ppap.200400078

45 von Keudell A, Awakowicz P, Benedikt J, Raballand V, YanguasGil A, Opretzka J, Flötgen C, Reuter R, Byelykh L, Halfmann H, Stapelmann K, Denis B, Wunderlich J, Muranyi P, Rossi F, Kylián O, Hasiwa N, Ruiz A, Rauscher H, Sirghi L, Comoy E, 
Dehen C, Challier L and Deslys JP: Inactivation of Bacteria and Biomolecules by Low-Pressure Plasma Discharges. Plasma Process Polym 7: 327-352, 2010. DOI: 10.1002/ppap.200900121

46 Winter T, Winter J, Polak M, Kusch K, Mäder U, Sietmann R, Ehlbeck J, van Hijum S, Weltmann K-D, Hecker M and Kusch $\mathrm{H}$ : Characterization of the global impact of low temperature gas plasma on vegetative microorganisms. Proteomics 11: 35183530, 2011. PMID: 21751354. DOI: 10.1002/pmic.201000637

47 Winter T, Bernhardt J, Winter J, Mäder U, Schlüter R, Weltmann K-D, Hecker M and Kusch H: Common versus noble Bacillus subtilis differentially responds to air and argon gas plasma. Proteomics 13: 2608-2621, 2013. PMID: 23794223. DOI: $10.1002 /$ pmic. 201200343

48 Bourke P, Ziuzina D, Han L, Cullen PJ and Gilmore BF: Microbiological interactions with cold plasma. J Appl Microbiol 123: 308-324, 2017. PMID: 28245092. DOI: $10.1111 /$ jam.13429

49 Liao X, Liu D, Xiang Q, Ahn J, Chen S, Ye X and Ding T: Inactivation mechanisms of non-thermal plasma on microbes: a review. Food Control 75: 83-91, 2017. DOI: 10.1016/ j.foodcont.2016.12.021

50 Brun P, Bernabè G, Marchiori C, Scarpa M, Zuin M, Cavazzana R, Zaniol B and Martines E: Antibacterial efficacy and mechanisms of action of low power atmospheric pressure cold plasma: membrane permeability, biofilm penetration and antimicrobial sensitization. J Appl Microbiol 125: 398-408, 2018. PMID: 29655267. DOI: 10.1111/jam.13780

51 Daeschlein G, von Woedtke Th, Kindel E, Brandenburg R, Weltmann K-D and Jünger M: Antibacterial Activity of an Atmospheric Pressure Plasma Jet Against Relevant Wound Pathogens in vitro on a Simulated Wound Environment. Plasma Process Polym 7: 224-230, 2010. DOI: 10.1002/ppap.2009 00059

52 Zimmermann JL, Dumler K, Shimizu T, Morfill GE, Wolf A, Boxhammer V, Schlegel J, Gansbacher B and Anton M: Effects of cold atmospheric plasmas on adenoviruses in solution. J Phys D Appl Phys 44: 505201, 2011. DOI: 10.1088/00223727/44/50/505201

53 Daeschlein G, Scholz S, Arnold A, von Podewils S, Haase H, Emmert S, von Woedtke Th, Weltmann K-D and Jünger M: In vitro susceptibility of important skin and wound pathogens against low temperature atmospheric pressure plasma jet (APPJ) and dielectric barrier discharge plasma (DBD). Plasma Process Polym 9: 380-389, 2012. DOI: 10.1002/ppap.20110 0160

54 Maisch T, Shimizu T, Li Y-F, Heinlin J, Karrer S, Morfill G and Zimmermann JL: Decolonisation of MRSA, S. aureus and E. coli by Cold-Atmospheric Plasma Using a Porcine Skin Model In Vitro. PLoS ONE 7: e34610, 2012. PMID: 22558091. DOI: 10.1371/journal.pone.0034610

55 Daeschlein G, Napp M, von Podewils S, Lutze S, Emmert S, Lange A, Klare I, Haase H, Gümbel D, von Woedtke Th and Jünger M: In vitro susceptibility of multidrug resistant skin and wound pathogens against low temperature atmospheric pressure plasma jet (APPJ) and dielectric barrier discharge plasma (DBD). Plasma Process Polym 11: 175-183, 2014. DOI: 10.1002/ppap.201300070

56 Klämpfl TG, Shimizu T, Koch S, Balden M, Gemein S, Li Y-F, Mitra A, Zimmermann JL, Gebel J, Morfill GE and Schmidt HU: Decontamination of nosocomial bacteria including clostridium difficile spores on dry inanimate surface by cold atmospheric plasma. Plasma Process Polym 11: 974-984, 2014. DOI: 10.1002/ppap.201400080

57 Gilmore BF, Flynn PB, O'Brien S, Hickok N, Freeman T and Bourke P: Cold plasmas for biofilm control: opportunities and challenges. Trends Biotechnol 36: 627-638, 2018. PMID: 29729997. DOI: $10.1016 /$ j.tibtech.2018.03.007

58 Guo L, Xu R, Gou L, Liu Z, Zhao Y, Liu D, Zhang L, Chen H and Kong MG: Mechanism of virus inactivation by cold atmospheric-pressure plasma and plasma-activated water. Appl Environ Microbiol 84: e00726-18, 2018. PMID: 29915117. DOI: 10.1128/AEM.00726-18

59 Isbary G, Morfill G, Schmidt HU, Georgi M, Ramrath K, Heinlin J, Karrer S, Landthaler M, Shimizu T, Steffes B, Bunk W, Monetti R, Zimmermann JL, Pompl R and Stolz W: A first prospective randomized controlled trial to decrease bacterial load using cold atmospheric argon plasma on chronic wounds in patients. Brit J Dermatol 163: 78-82, 2010. PMID: 20222930. DOI: 10.1111/j.1365-2133.2010.09744.x

60 Isbary G, Heinlin J, Shimizu T, Zimmermann JL, Morfill G, Schmidt HU, Monetti R, Steffes B, Bunk W, Li Y, Klaempfl T, Karrer S, Landthaler M and Stolz W: Successful and safe use of 2 min cold atmospheric argon plasma in chronic wounds: Results of a randomized controlled trial. Brit J Dermatol 167: 404-410, 2012. PMID: 22385038. DOI: 10.1111/j.13652133.2012.10923.x

61 Brehmer F, Haenssle HA, Daeschlein G, Ahmed R, Pfeiffer S, Görlitz A, Simon D, Schön MP, Wandke D and Emmert S: Alleviation of chronic venous leg ulcers with a hand-held dielectric barrier discharge plasma generator (PlasmaDerm ${ }^{\circledR}$ VU-2010): Results of a monocentric, two-armed, open, prospective, randomized and controlled trial (NCT01415622). J Eur Acad Dermatol Venereol 29: 148-155, 2015. PMID: 24666170. DOI: $10.1111 /$ jdv.12490

62 Ulrich C, Kluschke F, Patzelt A, Vandersee S, Czaika VA, Richter H, Bob A, von Hutten J, Painsi C, Hügel R, Kramer A, Assadian $\mathrm{O}$ and Lange-Asschenfeldt B: Clinical use of cold atmospheric pressure argon plasma in chronic leg ulcers: A pilot study. J Wound Care 24: 196-203, 2015. PMID: 25970756. DOI: $10.12968 /$ jowc.2015.24.5.196

63 Daeschlein G, Napp M, Lutze S, Arnold A, von Podewils S, Guembel D and Jünger M: Skin and wound decontamination of multidrug-resistant bacteria by cold atmospheric plasma coagulation. J Dtsch Dermatol Ges (JDDG) 13: 143-149, 2015. PMID: 25597338. DOI: $10.1111 / \mathrm{ddg} .12559$

64 Isbary G, Stolz W, Shimizu T, Monetti R, Bunk W, Schmidt HU, Morfill GE, Klämpfl TG, Steffes B, Thomas HM, Heinlin J, Karrer S, Landthaler M and Zimmermann JL: Cold atmospheric argon plasma treatment may accelerate wound healing in chronic wounds: Results of an open retrospective randomized controlled study in vivo. Clin Plasma Med 1(2): 25-30, 2013. DOI: $10.1016 /$ j.cpme.2013.06.001

65 Chuangsuwanich A, Assadamongkol T and Boonyawan D: The healing effect of low-temperature atmospheric-pressure plasma in pressure ulcer: A randomized controlled trial. Int J Low Extr Wound 15: 313-319, 2016. PMID: 27581113. DOI: 10.1177/ 1534734616665046

66 López-Callejas R, Peña-Eguiluza R, Valencia-Alvarado R, Mercado-Cabrera A, Rodríguez-Méndez BG, Serment-Guerrero JH, Cabral-Prieto A, González-Garduño AC, Domínguez- 
Cadena NA, Muñoz-Infante J and Betancourt-Ángeles M: Alternative method for healing the diabetic foot by means of a plasma needle. Clin Plasma Med 9: 19-23, 2018. DOI: 10.1016/ j.cpme.2018.01.001

67 Kramer A, Hübner N-O, Weltmann K-D, Lademann J, Ekkernkamp A, Hinz P and Assadian O: Polypragmasia in the therapy of infected wounds - conclusions drawn from the perspectives of low temperature plasma technology for plasma wound therapy. GMS Krankenhaushyg Interdiszip 3: Doc13, 2008. PMID: 20204115.

68 Kalghatgi S, Friedman G, Fridman A and Morss Clyne A: Endothelial Cell Proliferation is Enhanced by Low Dose NonThermal Plasma Through Fibroblast Growth Factor-2 Release. Ann Biomed Eng 38: 748-757, 2010. PMID: 20013154. DOI: 10.1007/s10439-009-9868-x

69 Arndt S, Unger P, Wacker E, Shimizu T, Heinlin J, Li Y-F, Thomas HM, Morfill GE, Zimmermann JL, Bosserhoff A-K and Karrer S: Cold Atmospheric Plasma (CAP) changes gene expression of key molecules of the wound healing machinery and improves wound Healing in vitro and in vivo. PLoS ONE 8: e79325, 2013. PMID: 24265766. DOI: 10.1371/journal.pone. 0079325

70 Haertel B, Eiden K, Deuter A, Wende K, von Woedtke Th and Lindequist U: Differential effect of non-thermal atmosphericpressure plasma on angiogenesis. Lett Appl NanoBioScience 3: 159-166, 2014

71 Haertel B, von Woedtke Th, Weltmann KD and Lindequist U: Non-thermal atmospheric-pressure plasma possible application in wound healing. Biomol Ther 22: 477-490, 2014. PMID: 25489414. DOI: $10.4062 /$ biomolther.2014.105

72 Thi Ngo M-H, Liao J-D, Shao P-L, Weng C-C and Chang C-Y: Increased Fibroblast Cell Proliferation and Migration Using Atmospheric $\mathrm{N}_{2} /$ Ar Micro-Plasma for the Stimulated Release of Fibroblast Growth Factor-7. Plasma Process Polym 11: 8088, 2014. DOI: 10.1002/ppap.201300098

73 Lendeckel D, Eymann C, Emicke P, Daeschlein G, Darm K, O'Neil S, Beule AG, von Woedtke Th, Völker U, Weltmann KD, Jünger M, Hosemann W and Scharf C: Proteomic changes of tissue-tolerable plasma treated airway epithelial cells and their relation to wound healing. Biomed Res Int 2015: 506059, 2015. PMID: 26539504. DOI: 10.1155/2015/506059

74 Choi JH, Song YS, Song K, Lee HJ, Hong JW and Kim GC: Skin renewal activity of nonthermal plasma through the activation of $\beta$-catenin in keratinocytes. Sci Rep 7: 6146, 2017. PMID: 28733577. DOI: 10.1038/s41598-017-06661-7

75 Kang SU, Choi JW, Chang JW, Kim KI, Kim YS, Park JK, Kim YE, Lee YS, Yang SS and Kim C-H: $\mathrm{N}_{2}$ non-thermal atmospheric pressure plasma promotes wound healing in vitro and in vivo: Potential modulation of adhesion molecules and matrix metalloproteinase-9. Exp Dermatol 26: 163-170, 2017. PMID: 27673439. DOI: 10.1111/exd.13229

76 Schmidt A, Bekeschus S, Wende K, Vollmar B and von Woedtke Th: A cold plasma jet accelerates wound healing in a murine model of full-thickness skin wounds. Exp Dermatol 26: 156-162, 2017. PMID: 27492871. DOI: 10.1111/exd.13156

77 Nastuta AV, Topala I, Grigoras C, Pohoata V and Popa G: Stimulation of wound healing by helium atmospheric pressure plasma treatment. J Phys D Appl Phys 44: 105204, 2011. DOI: 10.1088/0022-3727/44/10/105204

78 García-Alcantara E, López-Callejas R, Morales-Ramírez PR, Peña-Eguiluz R, Fajardo-Muñoz R, Mercado-Cabrera A, Barocio SR, Valencia-Alvarado R, Rodríguez-Méndez BG,
Muñoz-Castro AE, de la Piedad-Beneitez A and Rojas-Olmedoa IA: Accelerated mice skin acute wound healing in vivo by combined treatment of argon and helium plasma needle. Arch Med Res 44: 169-177, 2013. PMID: 23506720. DOI: 10.1016/ j.arcmed.2013.02.001

79 Hirata T, Kishimoto T, Tsutsui C, Kanai T and Mori A: Healing burns using atmospheric pressure plasma irradiation. Jpn J Appl Phys 53: 010302, 2014. DOI: 10.7567/JJAP.53.010302

80 Ngo Thi M-H, Shao P-L, Liao J-D, Lin C-CK and Yip H-K: Enhancement of Angiogenesis and Epithelialization Processes in Mice with Burn Wounds through ROS/RNS Signals Generated by Non-Thermal $\mathrm{N}_{2} / \mathrm{Ar}$ Micro-Plasma. Plasma Process Polym 11: 1076-1088, 2014. DOI: 10.1002/ppap. 201400072

81 Nasruddin, Nakajima Y, Mukai K, Rahayu HSE, Nur M, Ishijima T, Enomoto H, Uesugi Y, Sugama J and Nakatani T: Cold plasma on full-thickness cutaneous wound accelerates healing through promoting inflammation, re-epithelialization and wound contraction. Clin Plasma Med 2: 28-35, 2014. DOI: 10.1016/j.cpme.2014.01.001

82 Lee OJ, Ju HW, Khang G, Sun PP, Rivera J, Cho JH, Park S-J, Eden JG and Park $\mathrm{CH}$ : An experimental burn wound-healing study of non-thermal atmospheric pressure microplasma jet arrays. J Tissue Eng Regen Med 10: 348-357, 2016. PMID: 26227832. DOI: $10.1002 /$ term.2074

83 Kang SK, Kim HY, Yun GS and Lee JK: Portable microwave air plasma device for wound healing. Plasma Sources Sci Technol 24: 035020, 2015. DOI: 10.1088/0963-0252/24/3/ 035020

84 Kim HY, Kang SK, Park SM, Jung HY, Choi BH, Sim JY and Lee JK: Characterization and Effects of Ar/Air Microwave Plasma on Wound Healing. Plasma Process Polym 12: 14231434, 2015. DOI: 10.1002/ppap.201500017I

85 Hung Y-W, Lee L-T, Peng Y-C, Chang C-T, Wong Y-K and Tung $\mathrm{K}-\mathrm{C}$ : Effect of a nonthermal-atmospheric pressure plasma jet on wound healing: An animal study. J Chin Med Assoc 79: 320-328, 2016. PMID: 27036493. DOI: 10.1016/j.jcma. 2015.06.024

86 Fathollah S, Mirpour S, Mansouri P, Dehpour AR, Ghoranneviss M, Rahimi N, Naraghi ZS, Chalangari R and Chalangari KM: Investigation on the effects of the atmospheric pressure plasma on wound healing in diabetic rats. Sci Rep 6: 19144, 2016. DOI: 10.1038/srep19144

$87 \mathrm{Rad}$ ZS and Davani FA: Non-thermal atmospheric pressure dielectric barrier discharge plasma source construction and investigation on the effect of grid on wound healing application. Clin Plasma Med 4: 56-64, 2016. DOI: 10.1016/j.cpme. 2016.11.002

88 Kubinova S, Zaviskova K, Uherkova L, Zablotskii V, Churpita $\mathrm{O}$, Lunov $\mathrm{O}$ and Dejneka A: Non-thermal air plasma promotes the healing of acute skin wounds in rats. Sci Rep 7: 45183, 2017. DOI: $10.1038 /$ srep45183

89 Chatraie M, Torkaman G, Khani M, Salehi Hand Shokri B: In vivo study of non-invasive effects of non-thermal plasma in pressure ulcer treatment. Sci Rep 8: 5621, 2018. DOI: 10.1038/ s41598-018-24049-z

90 Arndt S, Schmidt A, Karrer S and von Woedtke Th: Comparing two different plasma devices kINPen and Adtec SteriPlas regarding their molecular and cellular effects on wound healing. Clin Plasma Med 9: 24-33, 2018. DOI: 10.1016/j.cpme. 2018.01.002 
91 Metelmann H-R, von Woedtke Th, Bussiahn R, Weltmann KD, Rieck M, Khalili R, Podmelle F and Waite PD: Experimental Recovery of $\mathrm{CO}_{2}$-Laser Skin Lesions by Plasma Stimulation. Am J Cosmetic Surg 29: 52-56, 2012. DOI: 10.5992/AJCS-D11-00042.1

92 Heinlin J, Zimmermann JL, Zeman F, Bunk W, Isbary G, Landthaler M, Maisch T, Monetti R, Morfill G, Shimizu T, Steinbauer J, Stolz W and Karrer S: Randomized placebocontrolled human pilot study of cold atmospheric argon plasma on skin graft donor sites. Wound Rep Regen 21: 800-807, 2013. PMID: 23937657. DOI: 10.1111/wrr.12078

93 Vandersee S, Richter H, Lademann J, Beyer M, Kramer A, Knorr $\mathrm{F}$ and Lange-Asschenfeldt B: Laser scanning microscopy as a means to assess the augmentation of tissue repair by exposition of wounds to tissue tolerable plasma. Laser Phys Lett 11: 115701, 2014. DOI: 10.1088/1612-2011/11/11/115701

94 Hartwig S, Doll C, Voss JO, Hertel M, Preissner S and Raguse JD: Treatment of Wound Healing Disorders of Radial ForearmFree Flap Donor Sites Using Cold Atmospheric Plasma: A Proof of Concept. J Oral Maxillofac Surg 75: 429435, 2017. PMID: 27637776. DOI: 10.1016/j.joms.2016.08.011

95 Jablonowski H, Hänsch MACh, Dünnbier M, Wende K, Hammer MU, Weltmann K-D, Reuter S and von Woedtke Th: Plasma jet's shielding gas impact on bacterial inactivation. Biointerphases 10: 029506, 2015. PMID: 25832438. DOI: 10.1116/1.4916533

96 Weavers H, Wood W and Martin P: Understanding the inflammatory response to tissue damage in Drosophila: a complex interplay of pro-inflammatory attractant signals, developmental priming and cytoprotection. 8th International Conference on Oxidative Stress in Skin Medicine and Biology, Andros, Greece, 6-9 September 2018, Book of Abstracts, p. 73.

97 Kalghatgi S, Kelly CM, Cerchar E, Torabi B, Alekseev O, Fridman A, Friedman G and Azizkhan-Clifford J: Effects of NonThermal Plasma on Mammalian Cells. PLoS ONE 6: e16270, 2011. PMID: 21283714. DOI: 10.1371/journal.pone. 0016270

98 Blackert S, Haertel B, Wende K, von Woedtke Th and Lindequist $\mathrm{U}$ : Influence of non-thermal atmospheric pressure plasma on cellular structures and processes in human keratinocytes (HaCaT). J Dermatol Sci 70: 173-181, 2013. PMID: 23619096. DOI: 10.1016/j.jdermsci.2013.01.012

99 Wende K, Straßenburg S, Haertel B, Harms M, Holtz S, Barton A, Masur K, von Woedtke Th and Lindequist U: Atmospheric pressure plasma jet treatment evokes transient oxidative stress in HaCaT keratinocytes and influences cell physiology. Cell Biol Int 38: 412-425, 2014. PMID: 24155089. DOI: 10.1002/ cbin. 10200

100 Oehmigen K, Winter J, Hähnel M, Wilke C, Brandenburg R, Weltmann K-D, von Woedtke Th: Estimation of Possible Mechanisms of Escherichia coli Inactivation by Plasma Treated Sodium Chloride Solution. Plasma Process Polym 8: 904-913, 2011. DOI: 10.1002/ppap.201000099

101.von Woedtke Th, Haertel B, Weltmann K-D and Lindequist U: Plasma pharmacy-physical plasma in pharmaceutical applications. Pharmazie 68: 492-498, 2013. PMID: 23923628. DOI: $10.1691 / \mathrm{ph} .2013 .6521$

102 Joslin JM, McCall JR, Bzdek JP, Johnson DC and Hybertson BM: Aqueous Plasma Pharmacy: Preparation Methods, Chemistry, and Therapeutic Applications. Plasma Med 6: 135-177, 2016. PMID: 28428835. DOI: 10.1615/PlasmaMed. 2016018618
103 Yan D, Talbot A, Nourmohammadi N, Cheng X, Canady J, Sherman J and Keidar M: Principles of using Cold Atmospheric Plasma Stimulated Media for Cancer Treatment. Sci Rep 5: 18339, 2015. DOI: 10.1038/srep18339

104 Tanaka H, Nakamura K, Mizuno M, Ishikawa K, Takeda K, Kajiyama H, Utsumi F, Kikkawa F and Hori M: Non-thermal atmospheric pressure plasma activates lactate in Ringer's solution for anti-tumor effects. Sci Rep 6: 36282, 2016. PMID: 27824103. DOI: $10.1038 /$ srep36282

105 Bekeschus S, Käding A, Schröder T, Wende K, Hackbarth C, Liedtke KR, van der Linde J, von Woedtke Th, Heidecke C-D and Partecke L-I: Cold Physical Plasma-Treated Buffered Saline Solution as Effective Agent Against Pancreatic Cancer Cells. Anticancer Agents Med Chem 18: 824-831, 2018. PMID: 29732979. DOI: $10.2174 / 1871520618666180507130243$

106 Graves DB: Oxy-nitroso shielding burst model of cold atmospheric plasma therapeutics. Clin Plasma Med 2: 38-49, 2014. DOI: $10.1016 /$ j.cpme.2014.11.001

107 Hamaguchi S, Ikuse K and Kanazawa T: Generation of free radicals in liquid by atmospheric-pressure plasmas and its application to biology and medicine. JPS Conf Proc 1: 015055 , 2014. DOI: 10.7566/JPSCP.1.015055

108 Wende K, Williams P, Dalluge J, van Gaens W, Aboubakr H, Bischop J, von Woedtke Th, Goyal SM, Bogaerts A, Masur K and Bruggeman PJ: Identification of the biologically active liquid chemistry induced by a nonthermal atmospheric pressure plasma jet. Biointerphases 10: 029518, 2015. PMID: 25947392. DOI: $10.1116 / 1.4919710$

109 Gorbanev Y, O'Connell D and Chechik V: Non-Thermal Plasma in Contact with Water: The Origin of Species. Chem Eur J 22: 1-11, 2016. PMID: 26833560. DOI: 10.1002/chem.201503771

110 Lietz AM and Kushner MJ: Air plasma treatment of liquid covered tissue: long timescale chemistry. J Phys D Appl Phys 49: 425204, 2016. DOI: 10.1088/0022-3727/49/42/425204

111 Verlackt CCW, Van Boxem W and Bogaerts A: Transport and accumulation of plasma generated species in aqueous solution. Phys Chem Chem Phys 20: 6845-6859, 2018. PMID: 2946 0930. DOI: $10.1039 / \mathrm{c} 7 \mathrm{cp} 07593 \mathrm{f}$

112 Go Y-M and Jones DP: Redox biology: Interface of the exposome with the proteome, epigenome and genome. Redox Biol 2: 358360, 2014. PMID: 24563853. DOI: 10.1016/j.redox. 2013.12.032

113 Holmström KM and Finkel T: Cellular mechanisms and physiological consequences of redox-dependent signalling. Nature Rev Mol Cell Biol 15: 411-421, 2014. PMID: 24854789. DOI: $10.1038 / \mathrm{nrm} 3801$

114 Lackmann J-W, Wende K, Verlackt C, Golda J, Volzke J, Kogelheide F, Held J, Bekeschus S, Bogaerts A, Schulz-von der Gathen V and Stapelmann K: Chemical fingerprints of cold physical plasmas - an experimental and computational study using cysteine as tracer compound. Sci Rep 8: 7736, 2018. DOI: $10.1038 / \mathrm{s} 41598-018-25937-0$

115 Bryan HK, Olayanju A, Goldring CE and Park BK: The Nrf2 cell defence pathway: Keap1-dependent and -independent mechanisms of regulation. Biochem Pharmacol 85: 705-717, 2013. PMID: 23219527. DOI: 10.1016/j.bcp.2012.11.016

116 Schmidt A, Dietrich S, Steuer A, Weltmann K-D, von Woedtke Th, Masur K and Wende K: Non-thermal plasma activates human keratinocytes by stimulation of antioxidant and phase II pathways. J Biol Chem 290: 6731-6750, 2015. PMID: 25589789. DOI: 10.1074/jbc.M114.603555 
117 Schmidt A, von Woedtke Th, Vollmar B, Hasse S and Bekeschus S: Nrf2 signaling and inflammation are key events in physical plasma-spurred wound healing. Theranostics 9: 1066-1084, 2019. PMID: 30867816. DOI: 10.7150/thno.29754

118 Arjunan KP, Sharma VK and Ptasinska S: Effects of Atmospheric Pressure Plasmas on Isolated and Cellular DNA A Review. Int J Mol Sci 16: 2971-3016, 2015. PMID: 25642755. DOI: $10.3390 / \mathrm{ijms} 16022971$

119 Boxhammer V, Li YF, Köritzer J, Shimizu T, Maisch T, Thomas HM, Schlegel J, Morfill GE and Zimmermann JL: Investigation of the mutagenic potential of cold atmospheric plasma at bactericidal dosages. Mutat Res-Gen Tox En 753: 23-28, 2013. PMID: 23416235. DOI: 10.1016/j.mrgentox.2012.12.015

120 Kluge S, Bekeschus S, Bender C, Benkhai H, Sckell A, Below $\mathrm{H}$, Stope MB and Kramer A: Investigating the Mutagenicity of a Cold Argon-Plasma Jet in an HET-MN Model. PLoS ONE 11: e0160667, 2016. PMID: 27584003. DOI: 10.1371/journal. pone. 0160667

121 Wende K, Bekeschus S, Schmidt A, Jatsch L, Hasse S, Weltmann $\mathrm{K}-\mathrm{D}$, Masur $\mathrm{K}$ and von Woedtke Th: Risk assessment of a cold argon plasma jet in respect to its mutagenicity. Mutat Res-Gen Tox En 798: 48-54, 2016. DOI: 10.1016/j.mrgentox.2016.02.003

122 Maisch T, Bosserhoff K, Unger P, Heider J, Shimizu T, Zimmermann JL, Morfill GE, Landthaler $\mathrm{M}$ and Karrer S: Investigation of Toxicity and Mutagenicity of Cold Atmospheric Argon Plasma. Environ Mol Mutagen 58: 172177, 2017. PMID: 28370324. DOI: $10.1002 / \mathrm{em} .22086$

123 Bekeschus S, Schmidt A, Kramer A, Metelmann H-R, Adler F, von Woedtke Th, Niessner F, Weltmann K-D and Wende K: High throughput image cytometry micronucleus assay to investigate the presence or absence of mutagenic effects of cold physical plasma. Environ Mol Mutagen 59: 268-277, 2018. PMID: 29417643. DOI: 10.1002/em.22172

124 Schmidt A, von Woedtke Th, Stenzel J, Lindner T, Polei S, Vollmar B and Bekeschus S: One year follow up risk assessment in SKH-1 mice and wounds treated with an argon plasma jet. Int J Mol Sci 18: 868, 2017. PMID: 28422070. DOI: 10.3390/ijms 18040868

125 von Woedtke Th, Metelmann H-R and Weltmann K-D: Editorial. Clin Plasma Med 1: 1-2, 2013. DOI: 10.1016/j.cpme. 2013.03.001

126 Hasse S, Hahn O, Kindler S, von Woedtke Th, Metelmann H$\mathrm{R}$ and Masur K: Atmospheric pressure plasma jet application on human oral mucosa modulates tissue regeneration. Plasma Med 4: 117-1129, 2014. DOI: 10.1615/PlasmaMed.2014011978

127 Hasse S, Tran T, Hahn O, Kindler S, Metelmann H-R, von Woedtke Th and Masur K: Induction of proliferation of basal epidermal keratinocytes by cold atmospheric pressure plasma. Clin Exp Dermatol 41: 202-209, 2015. PMID: 26175125. DOI: 10.1111/ced.12735

128 Heinlin J, Isbary G, Stolz W, Morfill G, Landthaler M, Shimizu T, Steffes B, Nosenko T, Zimmermann JL and Karrer S: Plasma applications in medicine with a special focus on dermatology. J Eur Acad Dermatol 25: 1-11, 2011. PMID: 20497290. DOI: 10.1111/j.1468-3083.2010.03702.x

129 Metelmann H-R, Vu TT, Do HT, Le TNB, Hoang THA, et al: Scar formation of laser skin lesions after cold atmospheric pressure plasma (CAP) treatment: A clinical long term observation. Clin Plasma Med 1: 30-35, 2013. DOI: 10.1016/ j.cpme.2012.12.001
130 Sen CK and Roy S: Redox signals in wound healing. Biochim Biophys Acta 1780: 1348-1361, 2008. PMID: 18249195. DOI: 10.1016/j.bbagen.2008.01.006

131 Dunnill C, Patton T, Brennan J, Barrett J, Dryden M, Cooke J, Leaper D and Georgopoulos NT: Reactive oxygen species (ROS) and wound healing: the functional role of ROS and emerging ROS-modulating technologies for augmentation of the healing process. Int Wound J 14: 89-96, 2017. PMID: 26688157. DOI: 10.1111/iwj.12557

132 Schmidt A and Bekeschus S: Redox for Repair: Cold Physical Plasmas and Nrf2 Signaling Promoting Wound Healing. Antioxidants 7: 146, 2018. PMID: 30347767. DOI: 10.3390/ antiox 7100146

133 Itoh K, Mochizuki M, Ishii Y, Ishii T, Shibata T, Kawamoto Y, Kelly V, Sekizawa K, Uchida $\mathrm{K}$ and Yamamoto $\mathrm{M}$ : Transcription factor Nrf2 regulates inflammation by mediating the effect of 15-deoxy-Delta(12,14)-prostaglandin j(2). Mol Cell Biol 24: 36-45, 2004. DOI: 10.1128/MCB.24.1.36-45.2004

134 Valcarcel-Ares MN, Gautam T, Warrington JP, Bailey-Downs L, Sosnowska D, de Cabo R, Losonczy G, Sonntag WE, Ungvari $\mathrm{Z}$ and Csiszar A: Disruption of Nrf2 signaling impairs angiogenic capacity of endothelial cells: implications for microvascular aging. J Gerontol A Biol Sci Med Sci 67: 821829, 2012. PMID: 22219515. DOI: $10.1093 /$ gerona/glr229

135 Huang Y, Li W, Su Z and Kong A-N T: The complexity of the Nrf2 pathway: beyond the antioxidant response. J Nutr Biochem 26: 1401-1413, 2015. PMID: 26419687. DOI: 10.1016/j.jnutbio.2015.08.001

136 Kobayashi EH, Suzuki T, Funayama R, NagashimaT, Hayashi M, SekineH, Tanaka N, Moriguchi T, Motohashi H, Nakayama K and Yamamoto M: Nrf2 suppresses macrophage inflammatory response by blocking proinflammatory cytokine transcription. Nature Comm 7: 11624, 2016. PMID: 27211851. DOI: 10.1038/ncomms11624

137 Li L, Pan H, Wang H, Li X, Bu X, Wang Q, Gao Y, Wen G, Zhou Y, Cong Z, Yang Y, Tang C and Liu Z: Interplay between VEGF and Nrf2 regulates angiogenesis due to intracranial venous hypertension. Sci Rep 6: 37338, 2016. PMID: 278691 47. DOI: $10.1038 /$ srep37338

138 Schmidt A, von Woedtke Th, Weltmann K-D and Masur K: Identification of the molecular basis of non-thermal plasmainduced changes in human keratinocytes. Plasma Med 3: 15-25, 2013. DOI: 10.1615/PlasmaMed.2014008535

139 Barton A, Wende K, Bundscherer L, Hasse S, Schmidt A, Bekeschus S, Weltmann K-D, Lindequist U and Masur K: Nonthermal Plasma Increases Expression of Wound Healing Related Genes in a Keratinocyte Cell Line. Plasma Med 3: 125136 (2013). DOI: 10.1615/PlasmaMed.2014008540

140 Hammer MU, Forbrig E, Kupsch S, Weltmann K-D and Reuter S: Influence of Plasma Treatment on the Structure and Function of Lipids. Plasma Med 3: 97-114, 2013. DOI: 10.1615/ PlasmaMed.2014009708

141 Yusupov M, Wende K, Kupsch S, Neyts EC, Reuter S and Bogaerts A: Effect of head group and lipid tail oxidation in the cell membrane revealed through integrated simulations and experiments. Sci Rep 7: 5761, 2017. DOI:10.1038/s41598-01706412-8

142 Schmidt A, Bekeschus S, Jablonowski H, Barton A, Weltmann K$\mathrm{D}$ and Wende $\mathrm{K}$ : Role of ambient gas composition on cold physical plasma-elicited cell signaling in keratinocytes. Biophys J 112: 23972407, 2017. PMID: 28591612. DOI: 10.1016/ j.bpj.2017.04.030 
143 Schmidt A, Bekeschus S, Jarick K, Hasse S, von Woedtke Th and Wende K: Cold physical plasma modulates p53 and mitogenactivated protein kinase signaling in keratinocytes. Oxid Med Cell Longev 2019: 7017363, 2019. DOI: 10.1155/2019/7017363

144 Emmert S, Brehmer F, Hänßle H, Helmke A, Mertens N, Ahmed R, Simon D, Wandke D, Maus-Friedrichs W, Daeschlein G, Schön MP and Viöl W: Atmospheric pressure plasma in dermatology: Ulcus treatment and much more. Clin Plasma Med 1: 24-29, 2013. DOI: 10.1016/j.cpme.2012.11.002

145 Hilker L, von Woedtke Th, Weltmann K-D and Wollert H-G: Cold atmospheric plasma: A new tool for the treatment of superficial driveline infections. Eur J Cardiothorac Surg 51: 186-187, 2017. PMID: 27354253. DOI: 10.1093/ejcts/ezw212

146 Wirtz M, Stoffels I, Dissemond J, Schadendorf D and Roesch A: Actinic keratoses treated with cold atmospheric plasma. J Eur Acad Dermatol 32: e37-e39, 2018. PMID: 28695987. DOI: $10.1111 / j d v .14465$

147 Martines E, Brun P, Brun P, Cavazzana R, Deligianni V, Leonardi A, Tarricone E and Zuin M: Towards a plasma treatment of corneal infections. Clin Plasma Med 1(2): 17-24, 2013. DOI: $10.1016 /$ j.cpme.2013.10.001

148 Alekseev O, Donovan K, Limonnik V and Azizkhan-Clifford J: Nonthermal dielectric barrier discharge (DBD) plasma suppresses herpes simplex virus type 1 (HSV-1) replication in corneal epithelium. Trans Vis Sci Tech 3: 2, 2014. PMID: 24757592. DOI: $10.1167 /$ tvst.3.2.2

149 Reitberger HH, Czugala M, Chow C, Mohr A, Burkovski A, Gruenert AK, Schoenebeck R and Fuchsluger TA: Argon cold plasma - A novel tool to treat therapy-resistant corneal infections. Am J Ophthalmol 190: 150-163, 2018. PMID: 29580975. DOI: 10.1016/j.ajo.2018.03.025

150 Cha S and Park Y-S: Plasma in dentistry. Clin Plasma Med 2: 4-10, 2014. PMID: 27030818. DOI: 10.1016/j.cpme.2014 04.002

151 Metelmann H-R, von Woedtke Th, Weltmann K-D (eds): Comprehensive Clinical Plasma Medicine. Cold Physical Plasma for Medical Application. Springer International Publishing AG, part of Springer Nature 2018, 526 p. DOI: 10.1007/978-3-319-67627-2

152 Schlegel J, Köritzer J and Boxhammer V: Plasma in cancer treatment. Clin Plasma Med 1(2): 2-7, 2013. DOI: 10.1016/ j.cpme.2013.08.001

153 Ratovitski EA, Cheng X, Yan D, Sherman JH, Canady J, Trink B and Keidar M: Anti-cancer therapies of 21st century: Novel approach to treat human cancers using cold atmospheric plasma. Plasma Process Polym 11: 1128-1137, 2014. DOI: 10.1002/ppap.201400071

154 Hirst AM, Frame FM, Arya M, Maitland NJ and O'Connell D: Low temperature plasmas as emerging cancer therapeutics: the state of play and thoughts for the future. Tumor Biol 37: 70217031, 2016. PMID: 26888782. DOI: 10.1007/s13277-016-49117

155 Dubuc A, Monsarrat P, Virard F, Merbahi N, Sarrette J-P, Laurencin-Dalicieux $\mathrm{S}$ and Cousty S: Use of cold-atmospheric plasma in oncology: a concise systematic review. Ther Adv Med Oncol 10: 1-12, 2018. PMID: 30046358. DOI: 10.1177/ 1758835918786475

156 Keidar M, Walk R, Shashurin A, Srinivasan P, Sandler A, Dasgupta S, Ravi R, Guerrero-Preston R and Trink B: Cold plasma selectivity and the possibility of a paradigm shift in cancer therapy. Brit J Cancer 105: 1295-1301, 2011. PMID: 21979421. DOI: $10.1038 /$ bjc.2011.386

157 Vandamme M, Robert E, Lerondel S, Sarron V, Ries D, Dozias S, Sobilo J, Gosset D, Kieda C, Legrain B, Pouvesle JM and Le Pape A: ROS implication in a new antitumor strategy based on non-thermal plasma. Int J Cancer 130: 2185-2194, 2012. PMID: 21702038. DOI: $10.1002 / \mathrm{ijc} .26252$

158 Graves DB: Reactive species from cold atmospheric plasma: Implications for cancer therapy. Plasma Process Polym 11: 1120-1127, 2014. DOI: 10.1002/ppap.201400068

159 Trachootham D, Alexandre J and Huang P: Targeting cancer cells by ROS-mediated mechanisms: a radical therapeutic approach? Nature Rev Drug Discov 8: 579-591, 2009. PMID: 19478820. DOI: $10.1038 /$ nrd2803

160 Yan D, Xiao H, Zhu W, Nourmohammadi N, Zhang LG, Bian $\mathrm{K}$ and Keidar $\mathrm{M}$ : The role of aquaporins in the antiglioblastoma capacity of the cold plasma-stimulated medium. J Phys D Appl Phys 50: 055401, 2017. DOI: 10.1088/13616463/aa53d6

161 Yan D, Cui H, Zhu W, Talbot A, Zhang LG, Sherman JH and Keidar M: The Strong Cell-based Hydrogen Peroxide Generation Triggered by Cold Atmospheric Plasma. Sci Rep 7: 10831, 2017. DOI: 10.1038/s41598-017-11480-x

162 Bauer G and Graves D: Mechanisms of Selective Antitumor Action of Cold Atmospheric Plasma-Derived Reactive Oxygen and Nitrogen Species. Plasma Process Polym 13: 1157-1178, 2016. DOI: 10.1002/ppap.201600089

163 Miller V, Lin A and Fridman A: Why target immune cells for plasma treatment of cancer. Plasma Chem Plasma Process 36: 259-268, 2016. DOI: 10.1007/s11090-015-9676-z

164 Bekeschus S, Mueller A, Miller V, Gaipl U and Weltmann K-D: Physical plasma elicits immunogenic cancer cell death and mitochondrial singlet oxygen. IEEE Trans Radiation Plasma Med Sci 2: 138-146, 2018. DOI: 10.1109/TRPMS.2017. 2766027

165 Partecke LI, Evert K, Haugk J, Doering F, Normann L, Diedrich S, Weiss FU, Evert M, Hübner NO, Guenther C, Heidecke CD, Kramer A, Bussiahn R, Weltmann K-D, Pati O, Bender $\mathrm{C}$ and von Bernstorff W: Tissue tolerable plasma (TTP) induces apoptosis in pancreatic cancer cells in vitro and in vivo. BMC Cancer 12: 473, 2012. PMID: 23066891. DOI: 10.1186/1471-2407-12-473

166 von Woedtke Th and Metelmann H-R: Editorial. Clin Plasma Med 2: 37, 2014. DOI: 10.1016/j.cpme.2014.11.002

167 Yoon YJ, Suh MJ, Lee HY, Lee HJ, Choi EH, Moon IS and Song K: Anti-tumor effects of cold atmospheric pressure plasma on vestibular schwannoma demonstrate its feasibility as an intra-operative adjuvant treatment. Free Radical Bio Med 115: 43-56, 2018. PMID: 29138018. DOI: 10.1016/j.freerad biomed.2017.11.011

168 Metelmann H-R, Nedrelow DS, Seebauer C, Schuster M, von Woedtke Th, Weltmann K-D, Kindler S, Metelmann PH, Finkelstein SE, Von Hoff DD and Podmelle F: Head and neck cancer treatment and physical plasma. Clin Plasma Med 3: 1723, 2015. DOI: 10.1016/j.cpme.2015.02.001

169 Schuster M, Seebauer C, Rutkowski R, Hauschild A, Podmelle F, Metelmann C, Metelmann B, von Woedtke Th, Hasse S, Weltmann K-D and Metelmann H-R: Visible Tumor Surface Response to Physical Plasma and Apoptotic Cell Kill in Head and Neck Cancer. J Cranio Maxill Surg 44: 1445-1452, 2016. PMID: 27499516. DOI: 10.1016/j.jcms.2016.07.001 
170 Metelmann H-R, Seebauer C, Miller V, Fridman A, Bauer G, Graves DB, Pouvesle J-M, Rutkowski R, Schuster M, Bekeschus S, Wende K, Masur K, Hasse S, Gerling T, Hori M, Tanaka H, Choi EH, Weltmann K-D, Metelmann PH, Von Hoff DD and von Woedtke Th: Clinical experience with cold plasma in the treatment of locally advanced head and neck cancer. Clin Plasma Med 9: 6-13, 2018. DOI: 10.1016/j.cpme.2017.09.001

171 Herrmann JM and Dick TP: Redox Biology on the rise. Biol Chem 393: 999-1004, 2012. PMID: 22944698. DOI: 10.1515/ hsz-2012-0111

172 Sies H: Strategies of antioxidant defense. Eur J Biochem 215: 213-219, 1993. PMID: 7688300. DOI: 10.1111/j.14321033.1993.tb18025.x

173 Jones DP and Radi R: Redox Pioneer: Professor Helmut Sies. Antioxid Redox Signal 21: 2459-2468, 2014. PMID: 25178739. DOI: $10.1089 /$ ars.2014.6037

174 Sies H: Oxidative stress: a concept in redox biology and medicine. Redox Biol 4: 180-183, 2015. PMID: 25588755. DOI: $10.1016 /$ j.redox.2015.01.002

175 Sies H, Berndt C and Jones DP: Oxidative Stress. Annu Rev Biochem 86: 715-748, 2017. PMID: 28441057. DOI: 10.1146/ annurev-biochem-061516-045037

176 Sies H: On the history of oxidative stress: Concept and some aspects of current development. Curr Opin Toxicol 7: 122-126, 2018. DOI: $10.1016 /$ j.cotox.2018.01.002

177 Sies H: Hydrogen peroxide as a central redox signaling molecule in physiological oxidative stress: Oxidative eustress. Redox Biol 11: 613-619, 2017. PMID: 28110218. DOI: 10.1016/j.redox.2016.12.035
178 Egea J, Fabregat I, Frapart YM, Ghezzi P, Görlach A et al: European contribution to the study of ROS: A summary of the findings and prospects for the future from the COST action BM1203 (EU-ROS). Redox Biol 13: 94-162, 2017. PMID: 28577489. DOI: 10.1016/j.redox.2017.05.007

179 Kaiser J: Hormesis. Sipping From a Poisoned Chalice. Science 302: 376-379, 2003. PMID: 14563981. DOI: 10.1126/science. 302.5644 .376

180 Calabrese EJ and Baldwin LA: Hormesis: The dose-response revolution. Annu Rev Pharmacol Toxicol 43: 175-197, 2003. PMID: 12195028. DOI: 10.1146/annurev.pharmtox.43.100901. 140223

181 Calabrese EJ, Bachmann KA, Bailer AJ, Bolger PM, Borak J et al: Biological stress response terminology: Integrating the concepts of adaptive response and preconditioning stress within a hermetic dose-response framework. Toxicol Appl Pharmacol 222: 122-128, 2007. DOI: 10.1016/j.taap.2007.02.015

182 Szili EJ, Harding FJ, Hong S-H, Herrmann F, Voelcker NH and Short RD: The hormesis effect of plasma-elevated intracellular ROS on HaCaT cells. J Phys D Appl Phys 48: 495401, 2015. DOI: $10.1088 / 0022-3727 / 48 / 49 / 495401$

Received March 7, 2019

Revised April 18, 2019

Accepted April 24, 2019 